\title{
CURRENT TRENDS IN ANTICANCER DRUG PROTOTYPE IN VITRO PHARMACOLOGY: BIBLIOMETRIC ANALYSIS 2019-2021
}

Ershov PV $\bowtie$, Makarova AS

Centre for Strategic Planning and Management of Biomedical Health Risks of the Federal Medical Biological Agency, Moscow, Russia

Identification of novel low molecular weight compounds with antitumor activity is the first important step towards the development of candidate drugs and a popular trend in in vitro pharmacology. The aim of the study was to assess the key trends and rank the scientific priorities in anticancer drug design using bibliometric analysis. The protocol involved using the panel of bibliographic databases (PubMed, Scopus, Cortellis) and analytical web-based tools PubChem, FACTA +, ClustVis, Reaxys, PathwayStudio and VOSviewer software to review a sample of 1657 papers issued 2020-2021. The work was also focused on 70 new promising basic structures and derivatives targeted at inhibiting both individual pro-tumor proteins and signaling cascades. It was found that serine-threonine protein kinases, receptor tyrosine kinases, DNA topoisomerases and tubulins as well as signaling pathways PI3K, mTOR, AKT1, STAT3, HIF-1a, and p53 account for up to $60 \%$ of the total structure of cellular targets for the design of anticancer drugs. The increasing scientific interest in innovative inhibitors of tumor-associated protein complexes, transcription factors and metabolic enzymes has been found. The compounds, which belong to heterocycles, glycosides, quinones and terpenes, were mentioned in $71 \%$ of papers as the basic structures for antitumor derivatives design. Papers, published in 2019, in which the compounds, such as lapachone, luteolin, quercetin, monastrol, and crisosplenol D are studied in the context of the design of new drug prototypes, have the highest citation rate. The systematic bibliometric approach involving the use of a panel of analytical resources makes it possible to assess R\&D trends and scientific priorities in anticancer drug design, thus organically complementing the classic reviews in periodicals.

Keywords: cancer, drugs, pharmacology, bibliometric analysis, publication activity, protein target

Author contribution: Ershov PV — literature search, manuscript writing and formatting, conceptualization of the paper; Makarova AS — literature search, manuscript editing.

$\triangle$ Correspondence should be addressed: Pavel V. Ershov

Pogodinskaya, 10, korp 1, Moscow, 119121; pavel79@inbox.ru

Received: 21.07.2021 Accepted: 18.08.2021 Published online: 27.09.2021

DOI: $10.47183 /$ mes.2021.033

\section{СОВРЕМЕННЫЕ ТЕНДЕНЦИИ IN VITRO ФАРМАКОЛОГИИ ПРОТОТИПОВ ПРОТИВООПУХОЛЕВЫХ ЛЕКАРСТВ: БИБЛИОМЕТРИЧЕСКИЙ АНАЛИЗ ЗА 2020-2021 ГГ.}

П. В. Ершов ${ }^{凶}$, А. С. Макарова

Центр стратегического планирования и управления медико-биологическими рисками Федерального медико-биологического агентства, Москва, Россия

Выявление новых низкомолекулярных соединений, обладающих противоопухолевой активностью, является первым важным шагом на пути создания кандидатных лекарств и популярным направлением в in vitro фармакологии. Целью исследования было оценить ключевые тенденции и ранжировать научные приоритеты в области дизайна противоопухолевых лекарств с применением библиометрического анализа. Протокол предполагал использование панели библиографических баз данных (PubMed, Scopus, Cortellis) и аналитических pecypcoв PubChem, FAcTA+, ClustVis, Reaxys, PathwayStudio и VOSviewer для исследования выборки из 1657 публикаций за 2020-2021 гг. В работе также систематизирован материал по 70 новым перспективным производным на основе базовых химических структур, нацеленных на ингибирование отдельных про-опухолевых белковых молекул и сигнальных каскадов. Установлено, что серин-треониновые протеинкиназы, рецепторные тирозинкиназы, ДНК-топоизомеразы и тубулины, а также сигнальные пути PI3K, mTOR, AKT1, STAT3, HIF-1а и р53 составляют до 60\% в общей структуре клеточных мишеней для дизайна противоопухолевых лекарств. Отмечен рост научного интереса к инновационным ингибиторам опухоль-ассоциированных белковых комплексов, факторов транскрипции и метаболических ферментов. Соединения из класса гетероциклов, гликозидов, хинонов и терпенов в 71\% работ служат базовыми структурами для дизайна противоопухолевых производных. Лидирующие позиции по цитированию занимают вышедшие в 2019 г. публикации, в которых рассмотрены такие соединения, как лапахон, лютеолин, кверцетин, монастрол и кризоспленол D, в контексте дизайна новых прототипов лекарств. Системный библиометрический подход с использованием панели аналитических ресурсов позволяет оценить тенденции в области разработки и дизайна противоопухолевых лекарств и выявить приоритеты научного интереса, органично дополняя классические обзорные работы в периодических изданиях.

Ключевые слова: рак, лекарства, фармакология, библиометрический анализ, публикационная активность, белковые мишени

Вклад авторов: П. В. Ершов — поиск литературы, написание и оформление текста статьи, концептуализация статьи; А. С. Макарова — поиск литературы, редактирование статьи.

$\triangle$ Для корреспонденции: Павел Викторович Ершов

ул. Погодинская, д. 10, стр. 1, г. Москва, 119121; pavel79@inbox.ru

Статья получена: 21.07.2021 Статья принята к печати: 18.08.2021 Опубликована онлайн: 27.09.2021

DOI: $10.47183 /$ mes.2021.033

Progress in the therapy of socially significant diseases, including malignant neoplasms (MN), is organically linked to success in research and development (R\&D) of the new drug prototypes, the pharmacologically active molecules, having the greatest antitumor effect and maximum conformity of physical and chemical parameters to canonical drug-like structures [1]. One of the evidence-based approaches to the drug discovery consists in design of molecules, which possess the desired properties and affect the cancer-related proteins [2-4]. Defining the mechanism of action of anticancer drug prototypes and the whole range of on-target and off-target proteins is essential for design of the highly selective drugs with minimal side effects. The development of the improved anticancer drugs follows from the properties of the tumor itself: intertumor and intratumor heterogeneity, and the diversity of mechanisms for resistance [5]. On the other hand, many pharmacotherapeutic approaches require improving the benefit-harm balance, since many existing anticancer drugs can cause severe side effects [6].

The number of annual publications dedicated to identification of the novel peptide and non-peptide molecules with anticancer activity, repositioning effects and prescriptions, is about 2700-3400 (over the five-year period, according to 
PubMed (accession on May 20, 2021). It should be noted that the review papers are focused mostly on systematizing the data on the anticancer drug prototypes, either belonging to a certain chemical taxon, or a spectrum of synthesized derivatives with the same chemical scaffold. Papers are also focused on discussing the range of biologically active substances with respect to the only molecular target. Nevertheless, reviews are a major source of scientific analysis in describing the current trends in drug discovery. Thus, the works [7, 8] cover the actual cancer-associated molecular targets, assessment of biological effects and concepts of the drug design, which in recent years has been intrinsically linked to computer-aided modeling (QSAR and others) [9]. At the same time, the search for current trends in drug prototypes, together with the interpretation of medical and biological effects of various anticancer compounds, results in the need for prompt data analysis from the multiple literature and biomedical sources. When performing without the use of customized algorithms and automated methods of data extraction (known as text mining), such an analysis can be very time-consuming. However, the application of the bibliometric analysis with adapted algorithms for creating an up-to-date "analytical portrait", which includes a more diversified repertoire of research data on drug prototypes and their molecular targets, has proved to be effective in defining the current trends in molecular oncology and pharmacology [10-13]. The aim of the study was to assess the key trends and rank the scientific priorities in anticancer drug design using bibliometric analysis.

\section{METHODS}

PubMed (https://pubmed.ncbi.nlm.nih.gov/) was used to search for journal papers (issued from May 20, 2020 to May 19, 2021) by keywords "antitumor and anticancer activity". Inclusion criteria was "original research" reporting the new data on identification of anticancer drug prototypes and the best relevancy of search. Exclusion criteria was paper types "Books and Documents", "Clinical Trial", "Meta-Analysis", "Randomized Controlled Trial", "Review" and "Systematic Review". A total of 1902 papers were found, from which 240 reviews and five clinical trials were subsequently excluded. 402 papers were selected from the remaining 1657 experimental papers, based on the abstracts analysis, and included in the target sample.

VOSviewer software [14] was used for keyword cooccurrence analysis in the papers from the target sample, as well as for keyword frequency analysis of MeSH terms and authors' terms in the papers' abstracts.

Names of low molecular weight non-peptide compounds were extracted from papers' abstracts and keyword listings. Their MeSH classification groups (Classification/Ontologie/ $\mathrm{MeSH}$-Tree) were defined using PubChem database (https:// pubchem.ncbi.nlm.nih.gov/).

Analysis of research trends and publication activity over the five-year period (2016-2020) was performed using the Scopus database (https://www.scopus.com/) (Elsevier; Netherlands). The key "compound name and tumor" (for example, "magnolol and tumor")was used as a search query. The scientific interest to papers, issued in 2019, was assessed by the total number of citations for papers issued before May 19, 2021, being corrected for self-citation of all co-authors of the paper. Another parameter was the average number of citations per paper, issued in 2019.

Associations between protein targets, their cancer significance and drug prototypes were analyzed using the Pathway Studio and Reaxys (Elsevier; Netherlands). These resources enable extracting the links between different molecular entities from biomedical data containing in twenty million abstracts and several million full-text papers with the help of Medscan software. They adapted for comprehensive search and prediction of drug targets as well as constructing of signaling pathways from the internal curated database. Associations found between molecular targets and key biological processes as "malignant transformation" and "cancer progression" was used to create the interaction map.

Web-based tool FACTA+ v.0.9 (accession on June 29, 2019) (http://www.nactem.ac.uk/facta/) was used to find biomedical associations in the full-text papers of the MEDLINE database.

Cortellis database (https://www.cortellis.com/intelligence) (Clarivate Analytics; UK) was used for patent search.

Principal component analysis (PCA) using k-means clustering and creating a heat map were performed using the ClustVis web-base tool [15]. The singular values decomposition method with imputation was used for PCA. It allows to generate and visualize the numeric data set geometric structure while imputing the missing values (imputation). Data preprocessing options included the following options: data transformation "no transformation"; row scaling - "no scaling". The heat map options were as follows: cluster distance for rows and columns Pearson correlation or "correlation", clustering method for rows and columns — "average".

\section{RESULTS}

Analysis of abstracts from the target sample (402 papers) made it possible to define distribution of the occurrence frequency for keywords, which were related to identification of anticancer drug prototype and were mentioned in the text massive more than 10 times (Fig. 1). Fig. 1 allows one to see the focus in studying the pharmacological targeting of signaling pathways involving RAC- $\alpha$ serine/threonine-protein kinase (AKT1), signal transducer and activator of transcription (STAT)-3, hypoxia-inducible factor $1-\alpha(\mathrm{HIF}-1 \alpha)$, and p53dependent pathways. Cancer-associated protein targets can be also distinguished: protein kinases (PKC and AMPK), tubulin, matrix metalloproteinases (MMP), poly (ADP-ribose) polymerase 1 (PARP1), epidermal growth factor receptor (EGFR), vascular endothelial growth factor (VEGFR). Furthermore, targeting of caspases, aimed at activation of apoptotic programs in tumor cells, provides another important field of research.

Visual representation of keyword co-occurrence, mentioned in more than three papers, is provided in Fig. 2. The figure presents five clusters with semantic links between the keywords. Thus, the pronounced co-occurrence was observed in the following keywords pairs: histone deacetylase-quinolines, topoisomerase inhibitors-indoles (or pyrazoles, or pyrimidines), tubulin modulators-chalcones (or naphthalenes). Thus, the analysis of papers abstracts and keyword co-occurrence (Fig. 1 and 2) made it possible to identify the studies focused on the design of chalcone and licochalcone (flavonoids with opened pyran ring), naphthalene, saponin, indole, quinolone, sesquiterpene, pyrazole, pyridine (pyrimidine), steroid, curcumin and britanin derivatives exhibiting anticancer activity. It is interesting to note that a sufficient number of papers were focused in the design optimization of tubulin polymerization inhibitors [16]. According to 10-year PubMed statistics, the number of new studies in this field remained stable, with a slight decline, observed in 2019-2020, which could demonstrate the decrease in scientific interest. Fig. 1 and 2 also show that 


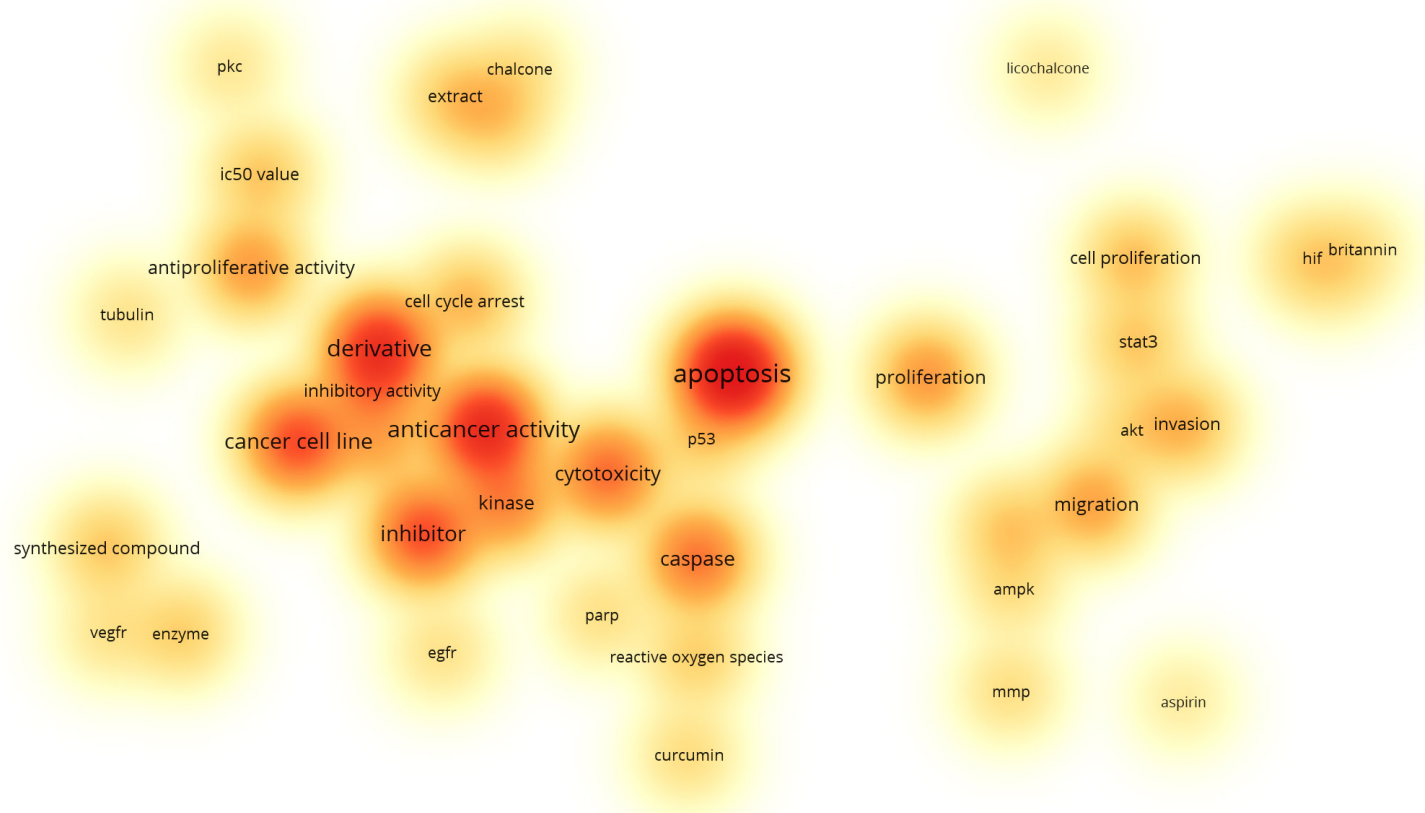

Fig. 1. Heat map of keyword (MeSH terms and authors' terms) mention frequency in the paper's abstracts

immortalized human embryonic kidney cell line HEK293, human colorectal carcinoma cell line HCT116, human lung carcinoma cell line A549, and mammary duct adenocarcinoma cell line (MCF-7) have become prevalent in vitro model systems. These were used for phenotype screening aimed at investigation of biological activity of novel drug prototypes, obtained by organic synthesis or extracted from plants, marine algae and fungi. Many medicinal plants are used in ethnopharmacology, for example, in China, which has provided the basis for the contribution of this country researchers from to the publication activities.
Fig. 3 demonstrates that compounds, representing the classes of heterocycles, glycosides, quinones and terpenes, appear to be the most abundant (71\%) in the pool of all chemicals. Attention should be drawn to the terpenes and terpenoids, which is of high scientific priority and is considered an active "donor" of basic structures for synthesis of anticancer drug prototypes [17]. Furthermore, assessing the occurrence frequency of compound names in the papers' abstracts showed that it was possible to distinguish at least 29 most popular chemical structures (acridine, anthraquinone, dibenzyl,

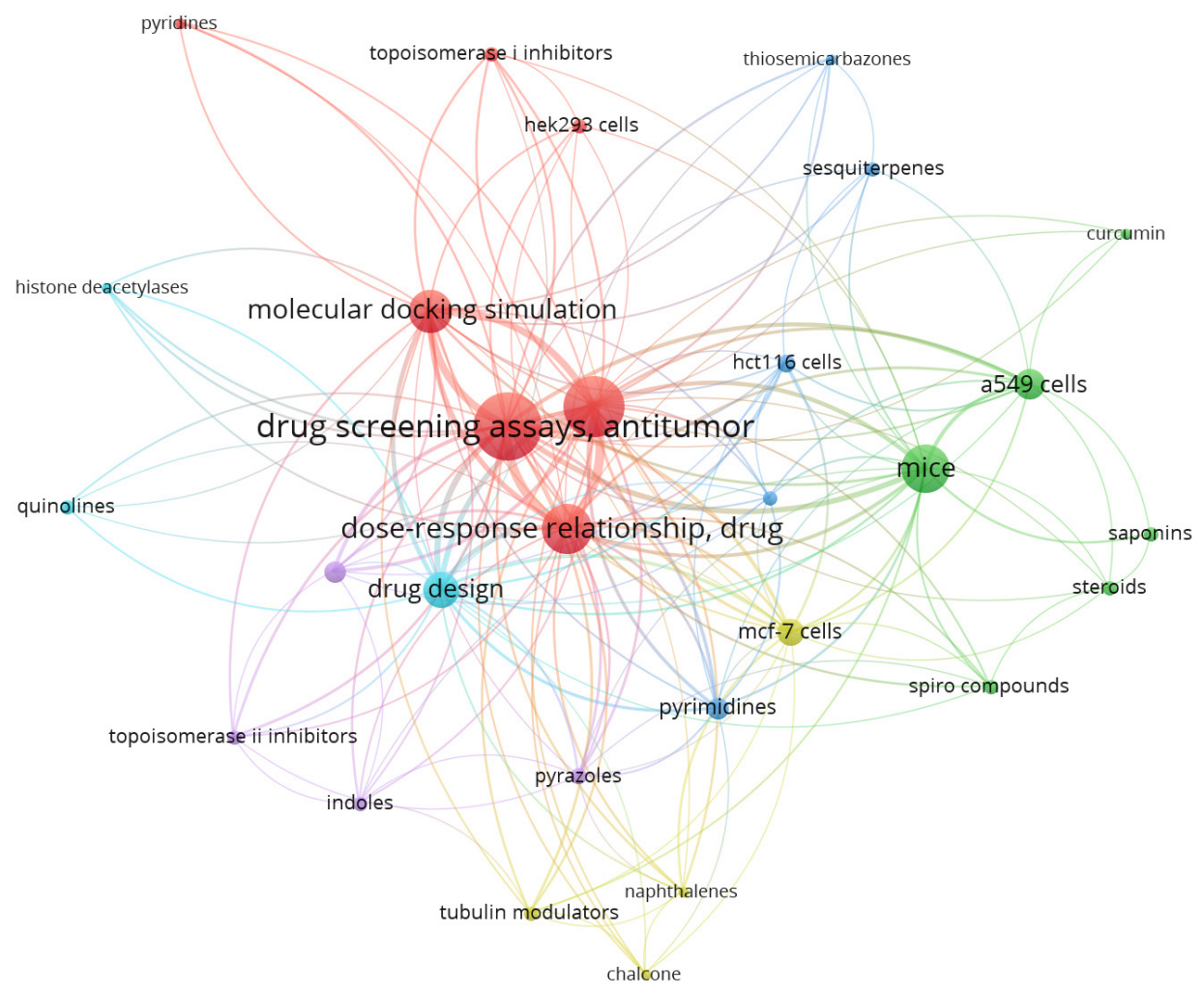

Fig. 2. Distribution of keyword (MeSH terms and authors' terms) co-occurrence based on the bibliographic data analysis 


\section{ОРИГИНАЛЬНОЕ ИССЛЕДОВАНИЕ І ФАРМАКОЛОГИЯ}

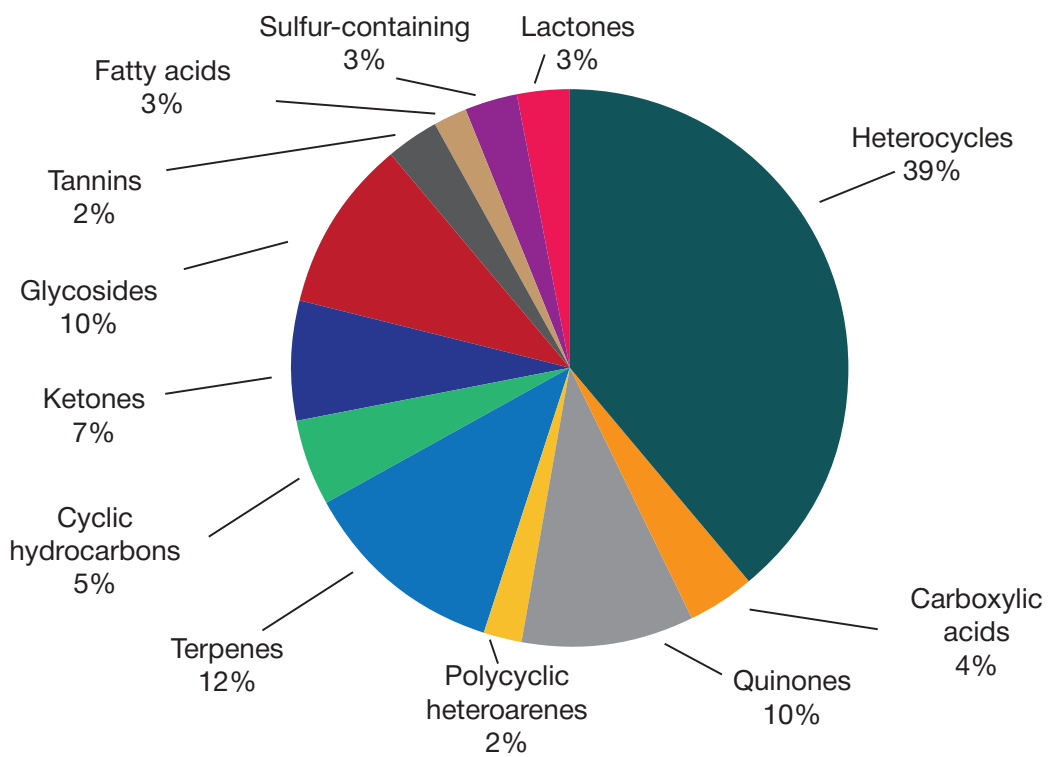

Fig. 3. The distribution of major groups of non-peptide organic compounds as new anticancer drug prototypes

stilbene, phenanthridine, pyranocarbazole, benzopyran, imidazolo-pyridine, indole, indolizine, naphthyridine, phthalazine, chinazoline) used for organic synthesis of new derivatives with anticancer activity and other spectrum [18, 19]. Thus, indole, quinazoline, acridine and pyridine derivatives in total account for $35 \%$ of all ones.

The trends of publication activity over the 5-year period (2016-2020) performed for 150 compounds, including the names of synthetic (46\%) and natural (54\%) chemical scaffolds, is presented in Fig. 4. It is reasonable to distinguish a discrete group of compounds (for example, derivatives of 1,6-naphthypyridone, sulfonylazaspirodienone, N-acyl-ophenylenediamine and scabioside $\mathrm{C}$ ), in which the anticancer activity was found for the first time. Fig. 4 also shows the reemerging scientific interest in dioscin, cinnoline, indolizine, nargenicin A1 derivatives and quercetin. It follows from the growing number of publications, issued in 2020, describing the new anticancer effects for these compounds. On the other

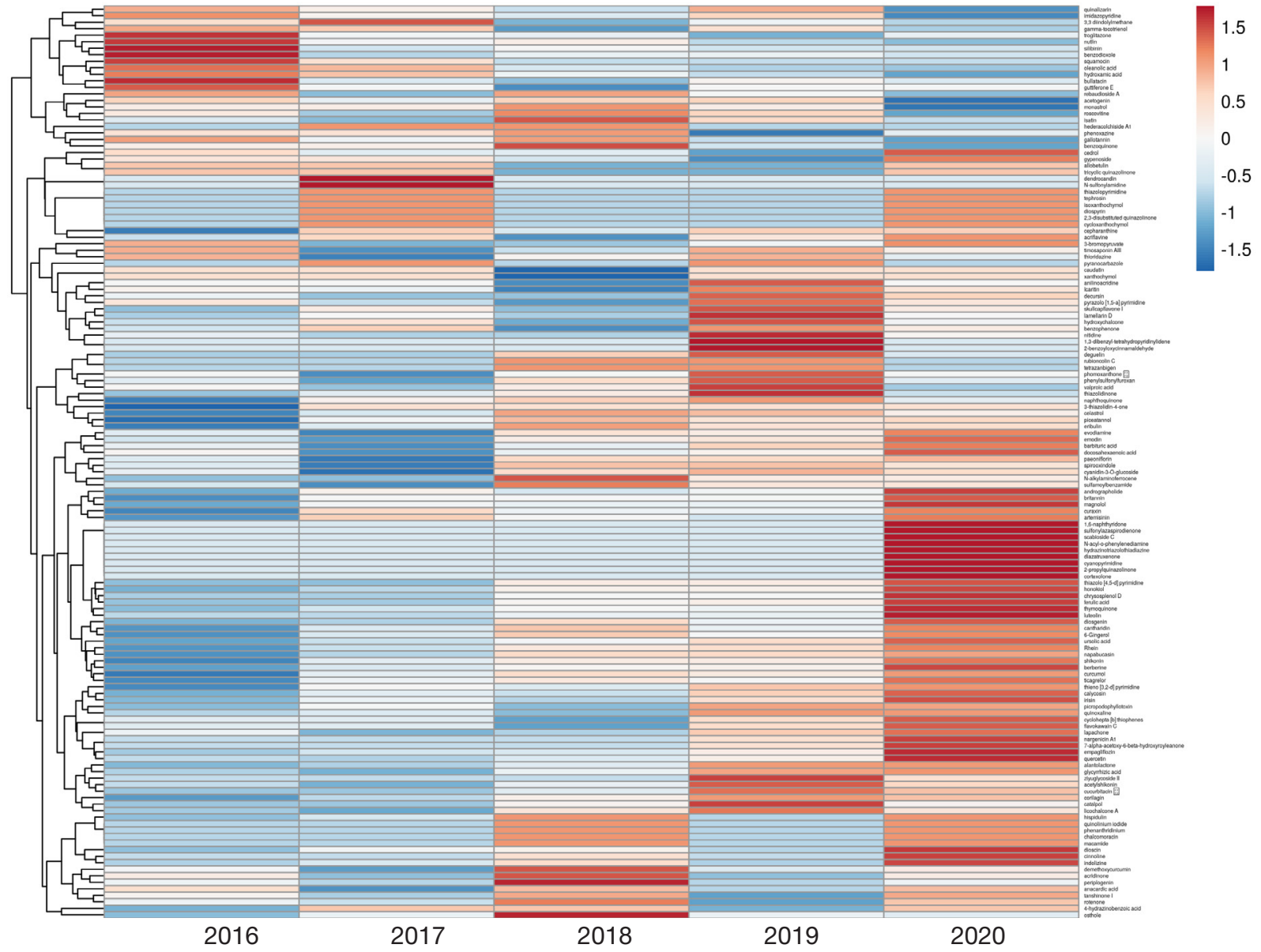

Fig. 4. Heat map of changes in publication activities (2016-2020) on identifying the new anticancer drug prototypes. Note: legend scale - cluster distance; decrease and increase in the number of papers are highlighted in red and blue colors, respectively 


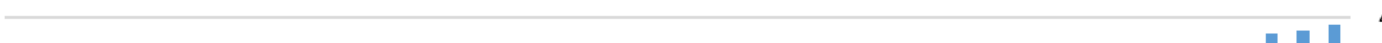

20

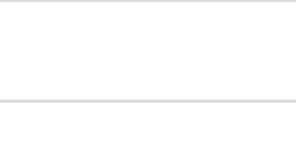

0

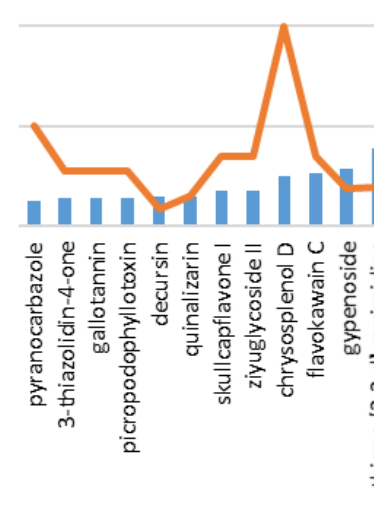

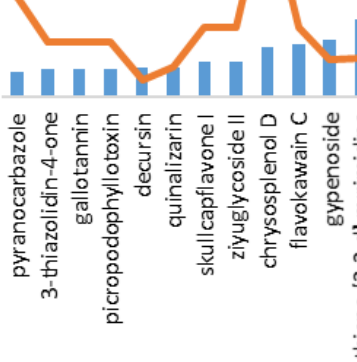
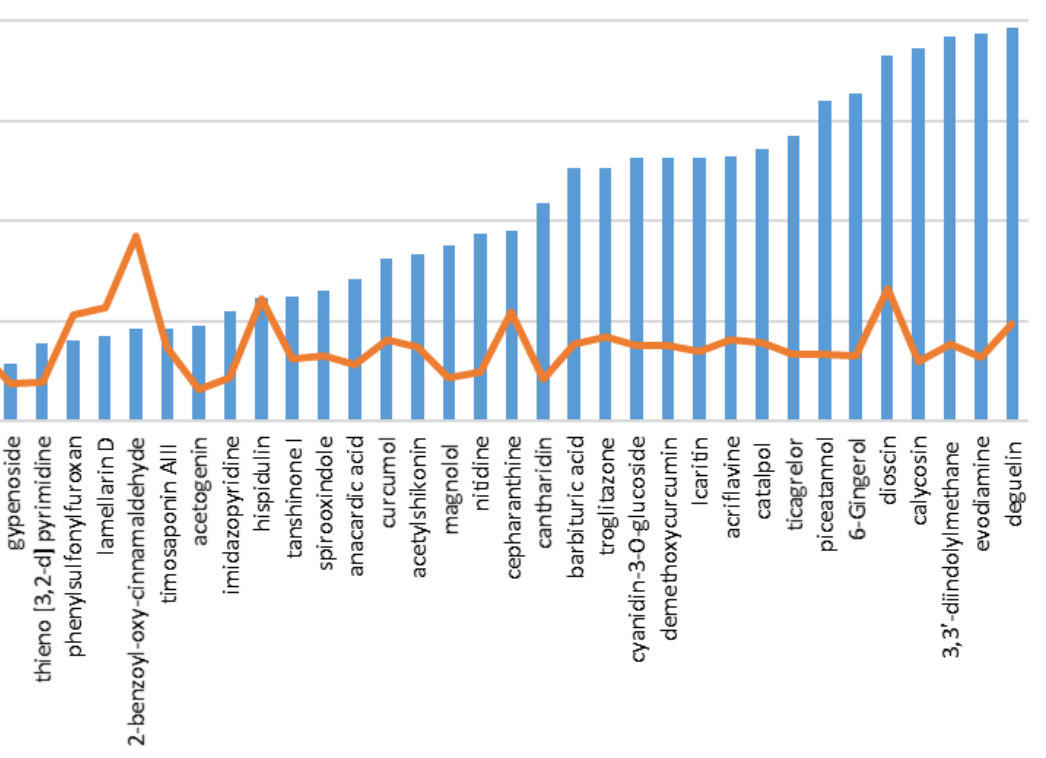

0

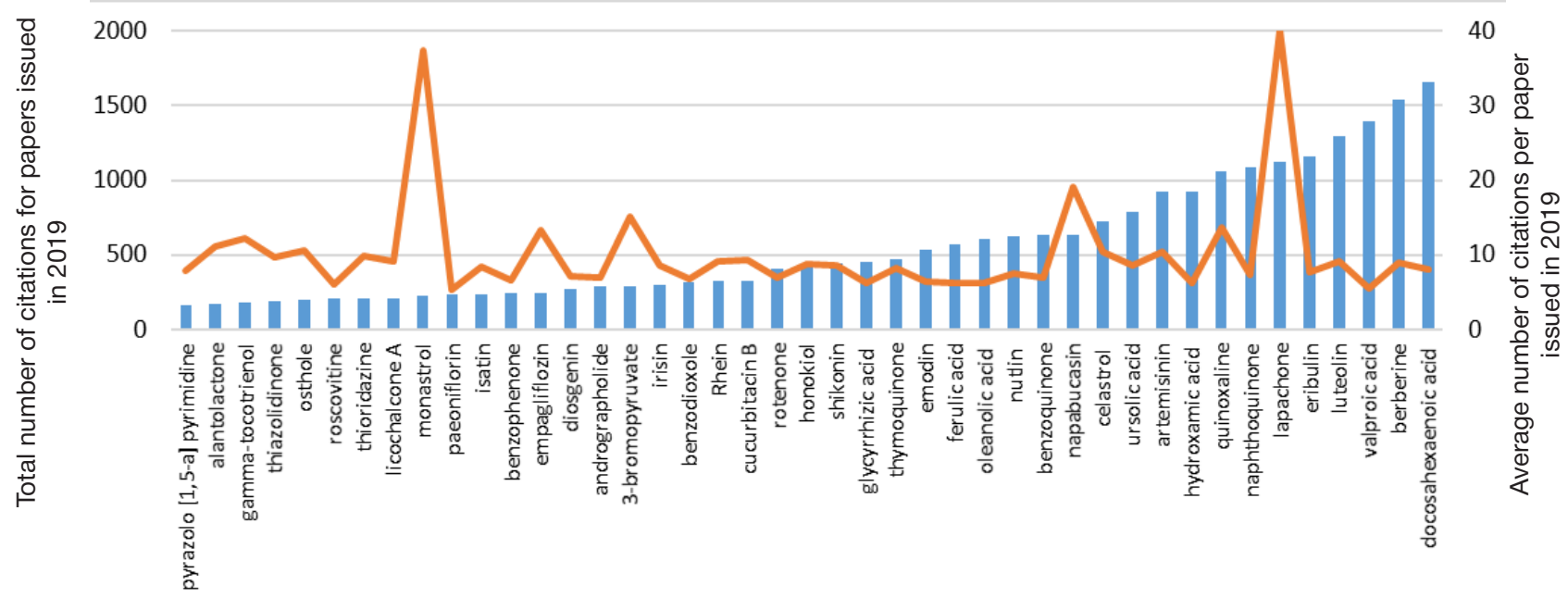

Fig. 5. Citations of papers issued in 2019 and focused on the anticancer drug prototype identification. Original names of compounds are provided

hand, publication activity with a reference to derivatives of thiazolidinedione (troglitazone), nutlin, silybin, squamocin, and derivatives of benzodioxole, oleanolic acid, and hydroxamic acid declined gradually in 2018-2020 compared to 2016-2017 period.

In addition to assessment of dynamic changes in the papers number, citing the papers, issued in 2019, was also analyzed. Fig. 5 shows that, citation rate in 2019-2021 (minimum threshold: 1000 citations) was observed for studies reffering quinoxaline, naphthoquinone, berberine, valproic acid and docosahexaenoic acid derivatives, as well as on lapachone, luteolin and quercetin. The latter is the "cite leader", which is mentioned 4200 times. However, based on the average number of citations per paper, issued in 2019, (minimum threshold: 15 citations), publications referring to crisosplenol D, 2-benzoyl-oxy-cinnamaldehyde, monastrol and lapachone ranked first in the context of new anticancer drug prototypes development.

The effective anticancer drug design is intrinsically linked with the related biomedical area of identifying the molecular targets. Efforts in this complementary area involve identification of mechanisms of action of drugs, which is critically important for differentiation of their on-target and off-target effects, as well as for design of highly selective compounds affecting the desired range of molecular targets. The vast majority of the clinically significant targets are the monomeric proteins or, more rarely, the oligomeric protein complexes [20]. Thus, the search for protein targets for a number of the priority anticancer drug prototypes (Fig. 5), contained in the Reaxys database, has helped to find out molecular targets has been mapped for the other three compounds, except crisosplenol D. As it turns out, the 2-benzoyloxycinnamaldehyde structure similar, ((E)2-(3-oxoprop-1-en-1-yl) phenyl benzoate), inhibits cyclindependent kinase 4, CDK4 (Target ID: 820056979) enzymatic activity, glutathione reductase (Target ID: 820106479) and farnesyltransferase (Target ID: 470858527). However, the monastrol and lapachone derivatives exhibit more optimal druglike properties (compliance with the "rule of five" parameters [21]) compared to 2-benzoyl-oxy-cinnamaldehyde, and have a greater potential for identification of their molecular target. Reaxys database contains 31 and 117 records (accession on May 29, 2021) about the monastrol and lapachone targets, respectively. Among them, it can be found Aurora A protein kinase (Reaxys Target ID:818366617), M-phase inducer phosphatase 2 (Target ID: 820046846), DNA topoisomerase I (Target ID: 818289566), DNA topoisomerase II (Target ID: 824645880), glutathione S-transferase P (Target ID: 820104166), K-Ras GTPase variants (Target ID: 819104337) with G12C and Q61R substitutions, $\mathrm{NAD}(\mathrm{P}) \mathrm{H}$ quinone dehydrogenase 1 (Target ID: 820009294).

In Table, the new experimental synthetic and natural compounds, exhibiting anticancer activity [22-92] were shown with respect to molecular target mapping and the mechanisms 


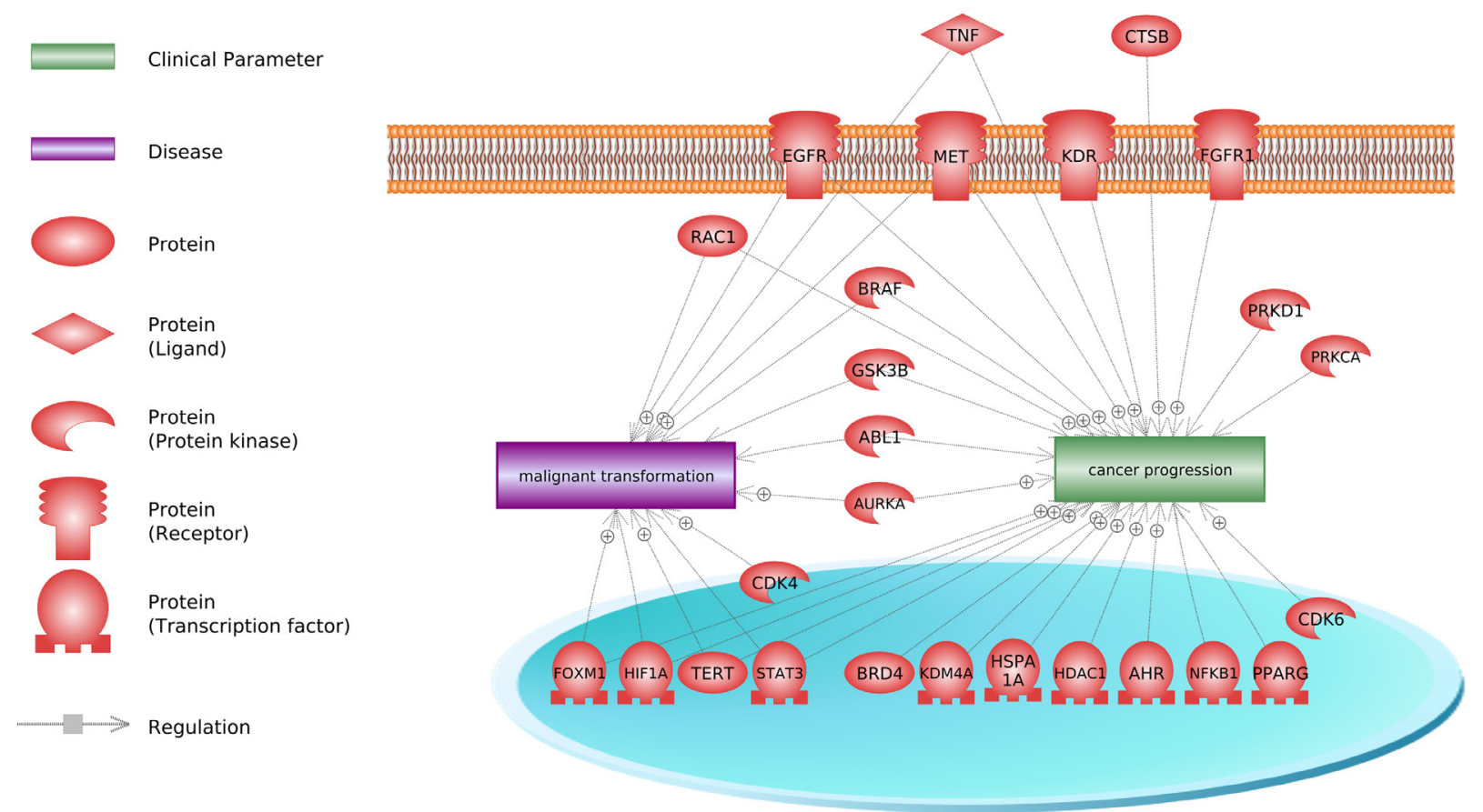

Fig. 6. Associations between the protein targets of anticancer drug prototypes returned by the queries "malignant transformation" and "cancer progression" in the Pathway Studio

of action studies. Scientific interest in such compounds follows from increased citation numbers and existence of patent potential. Furthermore, the newly identified chemical scaffolds, exhibiting a broad spectrum of anticancer activity, may later be used for design and synthesis of their derivatives. It is worth noting that papers on drug target mapping currently represent the great scintific demand and have a high citation rate in experimental pharmacology area.

\section{DISCUSSION}

Analysis of data presented in Table revealed the following quantitative distribution of the new anticancer drug protein targets: protein kinases (38\%), DNA topoisomerases I and II (10\%), transcription factors (9\%), clinically significant proteinprotein complexes (7\%), cytoskeleton proteins (tubulin) (5\%), and, finally, the rest of the diverse targets' group accounted for $40 \%$. It is noteworthy that the latter group included phosphodiesterase 5A (PDE5A), Na+-glucose cotransporter 2 (SGLT2), and glutathione S-transferase (GSTP1) and dihydrofolate reductase (DHFR) enzymes, associated with chemotherapy drug metabolism and involved in the drugresistant tumor phenotype formation [93]. Therefore, blockade of such enzymes may be considered a complementary pharmacological strategy, enabling to decrease chemoresistance. Analysis of papers' abstracts made it possible to determine the mechanism of action of anticancer drug prototypes (Table) which represent, mainly, competitive or noncompetitive reversible inhibition of the enzymes' catalytic activity.

Table demonstrates scientific interest in low molecular weight compounds that capable of modulating the function of transcription factors (for example, HIF-1a, FOXM1, ATF4). This is a group of intracellular nuclear proteins, which have been considered the extremely complicated molecular objects for drug design for a long time [94]. The search for new compounds disturbing signal transduction in the classic cancer-associated signaling pathways remains the traditional approach for carcinogenesis inhibition. Based on bibliometric analysis over 2020-2021, it should be pointed out that references to the PI3K, mTOR, AKT1, STAT3, HIF-1a and p53 signaling cascades were most often found among the pharmacologically targeted signaling pathways.

One more group can be seen in Table, including the compounds (LQFM126, E7386, britanin) and miconazole, which have the potential to selectively modulate the protein complex affinity. This approach to drug prototype design is innovative, since it is based on the pharmacological targeting of conservative interfaces of protein-protein interactions (PPI) with low mutation rate $[95,96]$. However, there is a number of polemical papers $[97,98]$, reporting the opposite, namely, predominant accumulation of mutations, associated with carcinogenesis, in the PPI interfaces of clinically significant protein complexes. This point is needed for in-depth study of the mutation factors' significance for drug targeted protein interfaces.

Then, we searched for information of involvement in carcinohenesis of the protein targets (listed in Table) using Pathway Studio. The assessment was performed based on the presence of links between proteins, and terms "malignant transformation" and "cancer progression". The results were selected on the availability of at least five papers, reporting the association of each protein target with each of these parameters. Thus, the visualization (Fig. 6) has revealed many evidence on the cancer involvement of majority of protein targets (Table).

The table also demonstrates that, on the one hand, STAT3 has been identified as a new protein target for the wellknown anticancer drug napabucasin. On the other hand, studying the repositioning effects of miconazole, troglitazone, dexamethasone, vinpocetine and empagliflozin has made it possible to determine one more type of their biological activity, that is the anticancer activity. It can be assumed that such activity results from the modulating of signal transduction in the pro-oncogene pathways.

Pathway Studio can help to found out that the main type of interaction between the protein targets, was a posttranslational modification by means of phosphorylation. The identified binary protein-protein interactions, where the first protein of a pair phosphorylates the second protein, are as follows: EGFR/STAT3, MET/STAT3, GSK3B/HIF1A, ABL1/ 
Table. Relationship between the biological activity of new anticancer drug prototypes and their molecular targets

\begin{tabular}{|c|c|c|}
\hline Biologically active compound & Description & Source \\
\hline \multicolumn{3}{|c|}{ Protein targets } \\
\hline LQFM126 & $\mathrm{PPI}^{*}$ inhibitor between MDM2 and p53 & [22] \\
\hline E7386 & PPI inhibitor between $\beta$-catenin and CREB & [23] \\
\hline Britanin & PPI inhibitor between HIF- $1 \alpha$ and Myc & [24] \\
\hline Miconazole* & PPI inhibitor between DDIAS and STAT3 & [25] \\
\hline $5 F-203$ & Activator of aryl hydrocarbon receptor (AHR) & [26] \\
\hline Emodin & Activator of AHR & [27] \\
\hline $\begin{array}{l}\text { 3/4-(pyrimidin-2-ylamino) benzoyl)-based } \\
\text { hydrazine-1-carboxamide/carbothioamide derivatives }\end{array}$ & Antagonist of retinoic acid receptor $\alpha(\mathrm{RXR} \alpha)$ & [28] \\
\hline 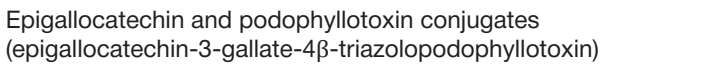 & Inhibitor of DNA topoisomerase II (TOP2) & [29] \\
\hline Tricyclic quinazolinone derivatives & Inhibitor of DNA topoisomerase I (TOP1) & [30] \\
\hline $\begin{array}{l}\text { 5(or 6)-nitro-2-(substitutedphenyl) benzo xazole, } \\
\text { 2-(substitutedphenyl) oxazolo[4,5-b] pyridine derivatives }\end{array}$ & Inhibitor of TOP1 and TOP2 & [31] \\
\hline Lamellarin D & Inhibitor of TOP1 & [32] \\
\hline Hoechst 33342 & Inhibitor of TOP1 & [33] \\
\hline $\begin{array}{l}\text { 3-(1H-indol-3-yl)-2,3,3a,4-tetrahydrothio chromeno[4,3-c] } \\
\text { pyrazole derivatives }\end{array}$ & Inhibitor of TOP2 & [34] \\
\hline 2,3-dihydropyrazino[1,2-a] indole-1,4-dione derivatives & $\begin{array}{l}\text { Inhibitor of EGFR tyrosine kinase and mutant } \\
\text { variant of serine/threonine kinase BRAF V600E }\end{array}$ & [35] \\
\hline 4-hydroxyquinazoline derivatives & Inhibitor of VEGFR2 tyrosine kinase & [36] \\
\hline DW14383 & Inhibitor of FGFR tyrosine kinase & [37] \\
\hline Chimeric compounds containing piperazine and chalcone & Inhibitor of VEGFR tyrosine kinase & [38] \\
\hline 1,6-naphthyridone derivatives & Inhibitor of c-MET tyrosine kinase & [39] \\
\hline $\mathrm{N}$-sulfonylamidine derivatives & Inhibitor of c-MET tyrosine kinase & [40] \\
\hline Di-2-pyridylketone 4,4-dimethyl-3-thiosemicarbazone (Dp44mT) & Inhibitor of AMPK protein kinase & [41] \\
\hline Tigilanol tiglate & Activator of protein kinase $\mathrm{C}(\mathrm{PKC})$ & [42] \\
\hline Epoxytigliane derivatives & Activators of protein kinase $\mathrm{C}(\mathrm{PKC})$ & [42] \\
\hline Isoxazolo[4,5-e] $[1,2,4]$ triazepine derivatives & Inhibitor of protein kinase C (PKC) & [43] \\
\hline Pyrazolo[3,4-d]pyrimidine derivatives & Inhibitor of protein kinase D (PKD) & [44] \\
\hline TAS-119 & Inhibitor of AURKA protein kinase & [45] \\
\hline Spirobibenzopyran derivatives & Inhibition of CDK4 protein kinase & [46] \\
\hline Pyrazolo [3,4-d] pyrimidine derivatives (Si306 and Si113) & Inhibitor of CDK $1 / 2$ protein kinases & [47] \\
\hline $7 \mathrm{H}-[1,2,4]$ triazolo $[3,4-\mathrm{b}][1,3,4]$ thiadiazine derivatives & Inhibitor of GSK-3 $\beta$ protein kinase & [48] \\
\hline Vinpocetine & Activator of GSK-3 $\beta$ protein kinase & [49] \\
\hline Thiazolyl hydrazone derivatives & Inhibitor of ABL1 protein kinase & [50] \\
\hline 5-(3-chlorophenylamino) benzo[c] $[2,6]$ naphthyridine derivatives & Inhibitor Casein kinase 2 (CK2) 2 & [51] \\
\hline WZ4003 & Inhibitor of AMPK-related kinase 5 & [52] \\
\hline N2817 & Inhibitor of BET1vesicular membrane trafficking protein & [53] \\
\hline Tetrazanbigen & Regulation of PPARy expression & [54] \\
\hline Calycosin & Regulation of apoptosis and miR-375 expression & [55] \\
\hline 3-bromopyruvate & Regulation of CTSB protease activity & [56] \\
\hline Decursin & $\begin{array}{c}\text { Regulation of HIF- } 1 \alpha \text { transcription factor expression and } \\
\text { degradation }\end{array}$ & [57] \\
\hline Troglitazone & Inhibitor of FOXM1 transcription factor activity & [58] \\
\hline Napabucasin & Inhibitor of STAT3 transcription factor & [59] \\
\hline $\mathrm{N}$-substituted sulfamoylbenzamide derivatives & Inhibitor of II-6/STAT3 activity & [60] \\
\hline Andrographolide & Regulation of ATF4 transcription factor activity & [61] \\
\hline Quinoline derivatives & Inhibitor of phosphodiesterase (PDE5) & [62] \\
\hline Osthole & Inhibitor of histone deacetylase (HDAC) & [63] \\
\hline Empagliflozin & Inhibitor of SGLT2 (SLC5A2) ion transporter & [64] \\
\hline Amb4269951 & Inhibitor of choline transporter-like protein CTL1 & [65] \\
\hline Evodiamine & Inhibitor of HSP70 chaperone & {$[66]$} \\
\hline
\end{tabular}


Table continued

\begin{tabular}{|c|c|c|}
\hline 6-(7-nitro-2,1,3-benzoxadiazol-4-ylthio) hexanol (NBDHEX) derivatives & Inhibitor of GSTP1 glutathione transferase & [67] \\
\hline BIBR1532 & Regulation of TERT telomerase activity & [68] \\
\hline Acetylshikonin & Inhibitor of DHFR dihydrofolate reductase & [69] \\
\hline Docosahexaenoic acid derivatives & Inhibitor of bromodomain-containing protein 4 (BRD4) & [70] \\
\hline Licochalcone A & Regulation of PD-L1 expression & [71] \\
\hline 2-amino-pyrrole-carboxamide derivatives & Inhibitor of tubulin polymerization & [72] \\
\hline 2,3-diaryl-2H-azirine derivatives & Inhibitor of tubulin polymerization & [73] \\
\hline Indolizine derivatives & Potential inhibitor of tubulin polymerization & [74] \\
\hline Rhein derivatives & Inhibitor of small GTPase Rac1 & [75] \\
\hline Dexamethasone & Regulation of p65 activity & [76] \\
\hline \multicolumn{3}{|c|}{ Signaling cascades as targets } \\
\hline Oleanolic acid and its semi-synthetic derivatives & $\mathrm{PI} 3 \mathrm{~K} / \mathrm{AKT} / \mathrm{mTOR}$ & [77] \\
\hline Gypenoside derivatives & $\mathrm{PI} 3 \mathrm{~K} / \mathrm{AKT} / \mathrm{mTOR}$ & [78] \\
\hline Cyanidin-3-O-glucoside derivatives & $\mathrm{PI} 3 \mathrm{~K} / \mathrm{AKT} / \mathrm{mTOR}$ & [79] \\
\hline IPM712 & PI3K/AKT & [80] \\
\hline Thieno[3,2-d]pyrimidine & $\mathrm{PI3K} / \mathrm{mTOR}$ & [81] \\
\hline Artemisinin & Wnt/ $\beta$-catenin & [82] \\
\hline PRI-724 & Wnt/ß-catenin & [83] \\
\hline Celastrol derivatives & $\mathrm{HIF}-1 \alpha$ & [84] \\
\hline Decursin & HIF- $1 \alpha$ & [85] \\
\hline Ursolic acid & JAK2/STAT3/EGFR & [86] \\
\hline Skullcapflavone I & JAK/STAT/MAPK & [87] \\
\hline Gallothanin & JAK/STAT & [88] \\
\hline Licochalcone A & MAPK & [89] \\
\hline Chrysin-chromene-spiroxyindole derivatives & p53 & [90] \\
\hline Picropodophyllotoxin & $\mathrm{JNK} / \mathrm{p} 38$ & [91] \\
\hline Luteolin & ERK/FOXO3a & [92] \\
\hline
\end{tabular}

Note: PPI — protein-protein interaction; * — approved medications are shown in italics.

STAT3, EGFR/GSK3B, ABL1/TERT, EGFR/MET, PRKCA/ GSK3B, ABL1/STAT3, AURKA/GSK3B, PRKD1/EGFR, GSK3B/HSPA1A, GSK3B/NFKB1. It should be emphasized that the above mentioned interactions include proteins, which are involved in carcinogenesis regulation and are the targets for the approved anticancer drugs [99, 100].

Thus, bibliomertic analysis of papers, issued in 2020-2021, focused on the identification and development of the novel non-peptide anticancer drug prototypes revealed the following findings: i) a significant proportion (71\%) of compounds belong to the chemical class of heterocycles, glycosides, quinones and terpenes; ii) indole, quinazoline, acridine and pyridine scaffolds were up to $35 \%$ from all used in organic synthesis of derivatives. Trend analysis of publication activity made it possible to define the scientific interest in the distinct groups of anticancer compounds and the progress in mapping their molecular targets. Among them, were proteins, associated with carcinogenesis, such as serine/threonine protein kinases, receptor tyrosine kinases, DNA topoisomerases and tubulins, which still remain the most studied anticancer drug targets. However, there are the increasing growth of the scientific interest in the design of inhibitors targeted to cancer-associated protein-protein complexes, transcription factors and metabolic enzymes, involved in the drug-resistant tumor phenotype.

\section{CONCLUSIONS}

Bibliometric approach with the using of Scopus, Reaxys, Pathway Studio and Cortellis databases together with VOS Viewer software enables prompt monitoring of the trends in the anticancer drug research and development (R\&D) as well as defining the priorities in current scientific interest. At the same time, it can be said that there emerges a growing number a growing number of novel molecular modalities associated with carcinogenesis processes, which encorages the studies discovery of more efficient pharmacotherapeutic agents.

\section{References}

1. Kiriiri GK, Njogu PM, Mwangi AN. Exploring different approaches to improve the success of drug discovery and development projects: a review. Futur J Pharm Sci. 2020; 6: 27. DOI: 10.1186/ s43094-020-00047-9.

2. Gibbs JB. Mechanism-based target identification and drug discovery in cancer research. Science. 2000; 287 (5460): 196973. DOI: 10.1126/science.287.5460.1969.
3. Druker BJ. Perspectives on the development of a molecularly targeted agent. Cancer Cell. 2002 Feb; 1 (1): 31-6. DOI: 10.1016/ s1535-6108(02)00025-9.

4. Nam NH, Parang K. Current targets for anticancer drug discovery. Curr Drug Targets. 2003; 4 (2): 159-79. DOI: 10.2174/1389450033346966.

5. Haider T, Pandey V, Banjare N, Gupta PN, Soni V. Drug resistance 
in cancer: mechanisms and tackling strategies. Pharmacol Rep. 2020; 72 (5): 1125-51. DOI:10.1007/s43440-020-00138-7.

6. Devlin EJ, Denson LA, Whitford HS. Cancer treatment side effects: A meta-analysis of the relationship between response expectancies and experience. J Pain Symptom Manage. 2017; 54 (2): 245-58.e2. DOI:10.1016/j.jpainsymman.2017.03.017.

7. Kumar B, Singh S, Skvortsova I, Kumar V. Promising targets in anti-cancer drug development: recent updates. Curr Med Chem. 2017; 24 (42): 4729-52. DOI: 10.2174/09298673246661703311 23648.

8. Magalhaes LG, Ferreira LLG, Andricopulo AD. Recent advances and perspectives in cancer drug design. An Acad Bras Cienc. 2018; 90 (1 Suppl 2): 1233-50. DOI: 10.1590/00013765201820170823.

9. Cui W, Aouidate A, Wang S, Yu Q, Li Y, Yuan S. Discovering anti-cancer drugs via computational methods. Front Pharmacol. 2020; 11: 733. DOI: 10.3389/fphar.2020.00733.

10. Özen Çınar İ. Bibliometric analysis of breast cancer research in the period 2009-2018. Int J Nurs Pract. 2020; 26 (3): e12845. DOI:10.1111/ijn.12845.

11. Didion CA, Henne WA. A bibliometric analysis of folate receptor research. BMC Cancer. 2020; 20 (1): 1109. DOI:10.1186/s12885020-07607-5.

12. Jin B, Wu XA, Du SD. Top 100 most frequently cited papers in liver cancer: a bibliometric analysis. ANZ J Surg. 2020; 90 (1-2): 21-6. DOI:10.1111/ans.15414

13. Liu W, Wu L, Zhang Y, Shi L, Yang X. Bibliometric analysis of research trends and characteristics of oral potentially malignant disorders. Clin Oral Investig. 2020; 24 (1): 447-54. DOI: 10.1007/ s00784-019-02959-0.

14. Van Eck NJ, Waltman L. Text mining and visualization using VOSviewer. ISSI Newsletter. 2011; 7 (3): 50-4.

15. Tauno M, Jaak V. Clustvis: a web tool for visualizing clustering of multivariate data using Principal Component Analysis and heatmap. Nucleic Acids Research. 2015; 43 (W1): W566-W570, 2015. DOI: $10.1093 / \mathrm{nar} / \mathrm{gkv} 468$

16. Arnst KE, Banerjee S, Chen H, Deng S, Hwang DJ, Li W, et al. Current advances of tubulin inhibitors as dual acting small molecules for cancer therapy. Med Res Rev. 2019; 39 (4): 1398426. DOI:10.1002/med.21568

17. Chopra B, Dhingra AK, Dhar KL, Nepali K. Emerging role of terpenoids for the treatment of cancer: a review. Mini Rev Med Chem. 2021. Available from: https://www.eurekaselect. com/190215/article. DOl: 10.2174/1389557521666210112143024.

18. Kirsch P, Hartman AM, Hirsch AKH, Empting M. Concepts and core principles of fragment-based drug design. Molecules. 2019; 24 (23): 4309. DOI: 10.3390/molecules24234309.

19. Giacomini E, Rupiani S, Guidotti L, Recanatini M, Roberti M. The use of stilbene scaffold in medicinal chemistry and multi-target drug design. Curr Med Chem. 2016; 23 (23): 2439-89. DOI: 10.2 174/0929867323666160517121629.

20. Hughes JP, Rees S, Kalindjian SB, Philpott KL. Principles of early drug discovery. Br J Pharmacol. 2011; 162 (6): 1239-49. DOI: 10.1111/j.1476-5381.2010.01127.x

21. Lipinski CA, Lombardo F, Dominy BW, Feeney PJ. Experimental and computational approaches to estimate solubility and permeability in drug discovery and development settings. Adv Drug Deliv Rev. 1997; 23 (1-3): 3-25. DOI: 10.1016/S0169-409X(96)00423-1.

22. Garcia da Silva AC, Rodrigues BDS, Andrade WM, Marques Dos Santos TR, de Carvalho FS, Sanz G, et al. Antiangiogenic and antitumoral activity of LQFM126 prototype against B16F10 melanoma cells. Chem Biol Interact. 2020; 325: 109127. DOI: 10.1016/i.cbi.2020.109127.

23. Yamada K, Hori Y, Inoue S, Yamamoto $Y$, Iso K, Kamiyama $H$, et al. E7386, a selective inhibitor of the interaction between $\beta$-catenin and CBP, exerts antitumor activity in tumor models with activated canonical Wnt signaling. Cancer Res. 2021; 81 (4): 1052-62. DOI: 10.1158/0008-5472.CAN-20-0782.

24. Zhang YF, Zhang ZH, Li MY, Wang JY, Xing Y, Ri M, et al. Britannin stabilizes $T$ cell activity and inhibits proliferation and angiogenesis by targeting PD-L1 via abrogation of the crosstalk between Myc and HIF-1 $\alpha$ in cancer. Phytomedicine. 2021; 81: 153425. DOl: 10.1016/i.phymed.2020.153425
25. Yoon SH, Kim BK, Kang MJ, Im JY, Won M. Miconazole inhibits signal transducer and activator of transcription 3 signaling by preventing its interaction with DNA damage-induced apoptosis suppressor. Cancer Sci. 2020 Jul; 111 (7): 2499-507. DOI: 10.1111/cas.14432. Epub 2020 May 31. PMID: 32476221; PMCID: PMC7385363.

26. Osmaniye D, Korkut Çelikateş B, Sağ lık BN, Levent S, Acar Çevik U, Kaya Çavușoğlu B, et al. Synthesis of some new benzoxazole derivatives and investigation of their anticancer activities. Eur J Med Chem. 2021; 210: 112979. DOI: 10.1016/j. ejmech.2020.112979.

27. Zhang N, Wang J, Sheng A, Huang S, Tang Y, Ma S, et al. Emodin inhibits the proliferation of MCF-7 human breast cancer cells through activation of aryl hydrocarbon receptor (AhR). Front Pharmacol. 2021; 11: 622046. DOI: 10.3389/fphar.2020.622046.

28. Qin J, Liu J, Wu C, Xu J, Tang B, Guo K, et al. Synthesis and biological evaluation of (3/4-(pyrimidin-2-ylamino) benzoyl)-based hydrazine-1 carboxamide/carbothioamide derivatives as novel RXR $\alpha$ antagonists. J Enzyme Inhib Med Chem. 2020; 35 (1): 880-96. DOI: 10.1080/14756366.2020.1740692.

29. Zi CT, Yang L, Hu Y, Zhang P, Tang H, Zhang BL, et al. Synthesis, antitumor activity, and molecular docking of (-)-epigallocatechin3-gallate-4 $\beta$-triazolopodophyllotoxin conjugates. J Asian Nat Prod Res. 2020: 1-9. DOI: 10.1080/10286020.2020.1786066.

30. Huang WY, Zhang XR, Lyu L, Wang SQ, Zhang XT. Pyridazino[1,6-b]quinazolinones as new anticancer scaffold: synthesis, DNA intercalation, topoisomerase I inhibition and antitumor evaluation in vitro and in vivo. Bioorg Chem. 2020; 99: 103814. DOI: 10.1016/j.bioorg.2020.103814.

31. Karatas E, Foto E, Ertan-Bolelli T, Yalcin-Ozkat G, Yilmaz S, Ataei S, et al. Discovery of 5-(or 6)-benzoxazoles and oxazolo[4,5-b]pyridines as novel candidate antitumor agents targeting hTopo llo. Bioorg Chem. 2021; 112: 104913. DOI: 10.1016/j.bioorg.2021.104913.

32. Fukuda T, Nanjo Y, Fujimoto M, Yoshida K, Natsui $Y$, Ishibashi F, et al. Lamellarin-inspired potent topoisomerase I inhibitors with the unprecedented benzo[g][1]benzopyrano[4,3-b]indol-6(13H)one scaffold. Bioorg Med Chem. 2019; 27 (2): 265-77. DOI: 10.1016/j.bmc.2018.11.037.

33. Acar Çevik U, Sağılı BN, Osmaniye D, Levent S, Kaya Çavuşoğlu B, Karaduman $A B$, et al. Synthesis, anticancer evaluation and molecular docking studies of new benzimidazole-1,3,4oxadiazole derivatives as human topoisomerase types I poison. J Enzyme Inhib Med Chem. 2020; 35 (1): 1657-73. DOI: 10.1080/14756366.2020.1806831.

34. Song Y, Feng S, Feng J, Dong J, Yang K, Liu Z, et al. Synthesis and biological evaluation of novel pyrazoline derivatives containing indole skeleton as anti-cancer agents targeting topoisomerase II. Eur J Med Chem. 2020; 200: 112459. DOI: 10.1016/j. ejmech.2020.112459.

35. Al-Wahaibi LH, Gouda AM, Abou-Ghadir OF, Salem OIA, Ali AT, Farghaly HS, et al. Design and synthesis of novel 2,3-dihydropyrazino[1,2-a]indole-1,4-dione derivatives as antiproliferative EGFR and BRAFV600E dual inhibitors. Bioorg Chem. 2020; 104: 104260. DOI: 10.1016/j.bioorg.2020.104260.

36. Eissa $\mathbb{H}$, Ibrahim MK, Metwaly AM, Belal A, Mehany ABM, Abdelhady AA, et al. Design, molecular docking, in vitro, and in vivo studies of new quinazolin-4(3H)-ones as VEGFR-2 inhibitors with potential activity against hepatocellular carcinoma. Bioorg Chem. 2021; 107: 104532. DOI: 10.1016/j.bioorg.2020.104532.

37. Dai MD, Wang YL, Fan J, Dai Y, Ji YC, Sun YM, et al. DW14383 is an irreversible pan-FGFR inhibitor that suppresses FGFRdependent tumor growth in vitro and in vivo. Acta Pharmacol Sin. 2020. Available from: https://www.nature.com/articles/s41401020-00567-3. DOI: 10.1038/s41401-020-00567-3.

38. Ahmed MF, Santali EY, El-Haggar R. Novel piperazine-chalcone hybrids and related pyrazoline analogues targeting VEGFR-2 kinase; design, synthesis, molecular docking studies, and anticancer evaluation. J Enzyme Inhib Med Chem. 2021; 36 (1): 307-18. DOl: 10.1080/14756366.2020.1861606.

39. Zhuo LS, Wu FX, Wang MS, Xu HC, Yang FP, Tian YG, et al. Structure-activity relationship study of novel quinazoline-based 1,6-naphthyridinones as MET inhibitors with potent antitumor efficacy. Eur J Med Chem. 2020; 208: 112785. DOI: 10.1016/j. 
ejmech.2020.112785.

40. Nan X, Zhang J, Li HJ, Wu R, Fang SB, Zhang ZZ, et al. Design, synthesis and biological evaluation of novel $\mathrm{N}$-sulfonylamidine based derivatives as c-Met inhibitors via Cu-catalyzed threecomponent reaction. Eur J Med Chem. 2020; 200: 112470. DOI: 10.1016/j.ejmech.2020.112470.

41. Krishan S, Sahni S, Richardson DR. The anti-tumor agent, Dp44mT, promotes nuclear translocation of TFEB via inhibition of the AMPK-mTORC1 axis. Biochim Biophys Acta Mol Basis Dis. 2020; 1866 (12): 165970. DOI: 10.1016/j.bbadis.2020.165970.

42. Cullen JK, Boyle GM, Yap PY, Elmlinger S, Simmons JL, Broit N, et al. Activation of PKC supports the anticancer activity of tigilanol tiglate and related epoxytiglianes. Sci Rep. 2021; 11 (1): 207. DOI: 10.1038/s41598-020-80397-9.

43. Wagner E, Wietrzyk J, Psurski M, Becan L, Turlej E. Synthesis and anticancer evaluation of novel derivatives of isoxazolo[4,5-e] $[1,2,4]$ triazepine derivatives and potential inhibitors of protein kinase C. ACS Omega. 2020; 6 (1): 119-34. DOI:10.1021/ acsomega.0c03801.

44. Gilles P, Kashyap RS, Freitas MJ, Ceusters S, Van Asch K, Janssens $A$, et al. Design, synthesis and biological evaluation of pyrazolo[3,4-d]pyrimidine-based protein kinase D inhibitors. Eur J Med Chem. 2020; 205: 112638. DOI: 10.1016/j. ejmech.2020.112638.

45. Sootome H, Miura A, Masuko N, Suzuki T, Uto $Y$, Hirai H, et al Inhibitor TAS-119 enhances antitumor efficacy of taxanes in vitro and in vivo: preclinical studies as guidance for clinical development and trial design. Mol Cancer Ther. 2020; 19 (10): 1981-91. DOI: 10.1158/1535-7163.MCT-20-0036.

46. Kar S, Ramamoorthy G, Mitra K, Shivalingegowda N, Mahesha Mavileti SK, et al. Synthesis of novel spirobibenzopyrans as potent anticancer leads inducing apoptosis in HeLa cells. Bioorg Med Chem Lett. 2020; 30 (12): 127199. DOI: 10.1016/j. bmcl.2020.127199.

47. Massaro M, Barone G, Barra V, Cancemi P, Di Leonardo A, Grossi G, et al. Pyrazole[3,4-d]pyrimidine derivatives loaded into halloysite as potential CDK inhibitors. Int J Pharm. 2021; 599: 120281. DOI: 10.1016/j.ijpharm.2021.120281.

48. Ismail MI, Mohamady S, Samir N, Abouzid KAM. Design, synthesis, and biological evaluation of novel $7 \mathrm{H}-[1,2,4]$ triazolo[3,4-b][1,3,4 thiadiazine inhibitors as antitumor agents. ACS Omega. 2020; 5 (32): 20170-86. DOI: 10.1021/acsomega.0c01829.

49. Zhang ZY, Dong SM, Liu YH, Zhang MM, Zhang JK, Zhu HJ et al. Enhanced anticancer activity by the combination of vinpocetine and sorafenib via PI3K/AKT/GSK-3 $\beta$ signaling axis in hepatocellular carcinoma cells. Anticancer Drugs. 2021 Available from: https://journals.Iww.com/anti-cancerdrugs/ Abstract/2021/09000/Enhanced_anticancer_activity_by_the combination of.7.aspx. DOI: 10.1097/CAD.0000000000001056.

50. Zeytün E, Altıntop MD, Sever B, Özdemir A, Ellakwa DE, Ocak Z, et al. A new series of antileukemic agents: design, synthesis, in vitro and in silico evaluation of thiazole-based abl1 kinase inhibitors. Anticancer Agents Med Chem. 2021; 21 (9): 1099-109. DOI: 10 2174/1871520620666200824100408.

51. Wang Y, LV Z, Chen F, Wang X, Gou S. Discovery of 5-(3-chlorophenylamino) benzo[c][2,6] naphthyridine derivatives as highly selective ck2 inhibitors with potent cancer cell stemness inhibition. J Med Chem. 2021; 64 (8): 5082-98. DOI: 10.1021/ acs.jmedchem.1c00131

52. Yang $H$, Wang $X$, Wang $C$, Yin F, Qu L, Shi C et al. Optimization of WZ4003 as NUAK inhibitors against human colorectal cancer. Eur J Med Chem. 2021; 210: 113080. DOI: 10.1016/j. ejmech.2020.113080.

53. Wu Q, Chen DQ, Sun L, Huan XJ, Bao XB, Tian CQ et al. Novel bivalent BET inhibitor N2817 exhibits potent anticancer activity and inhibits TAF1. Biochem Pharmacol. 2021; 185: 114435. DOI: 10.1016/j.bcp.2021.114435.

54. Gan L, Gan Z, Dan Y, Li Y, Zhang P, Chen S, et al. Tetrazanbigen derivatives as peroxisome proliferator-activated receptor gamma (ppary) partial agonists: design, synthesis, structure-activity relationship, and anticancer activities. J Med Chem. 2021; 64 (2): 1018-36. DOI: 10.1021/acs.jmedchem.0c01512.

55. Zhang D, Sun G, Peng L, Tian J, Zhang H. Calycosin inhibits viability, induces apoptosis, and suppresses invasion of cervical cancer cells by upregulating tumor suppressor miR-375. Arch Biochem Biophys. 2020; 691: 108478. DOI: 10.1016/j. abb.2020.108478.

56. Szczuka I, Wiśniewski J, Kustrzeba-Wójcicka I, Terlecki G. The effect of 3-bromopyruvate on the properties of cathepsin B in the aspect of metastatic potential of colon cancer cells. Adv Clin Exp Med. 2020; 29 (8): 949-57. DOI: 10.17219/acem/123622. PMID: 32820873

57. Ge $\mathrm{Y}$, Yoon $\mathrm{SH}$, Jang $\mathrm{H}$, Jeong JH, Lee $\mathrm{YM}$. Decursin promotes $\mathrm{HIF-1} \alpha$ proteasomal degradation and immune responses in hypoxic tumour microenvironment. Phytomedicine. 2020; 78 : 153318. DOI: 10.1016/j.phymed.2020.153318.

58. Tabatabaei Dakhili SA, Pérez DJ, Gopal K, Haque M, Ussher JR, Kashfi K, et al. SP1-independent inhibition of FOXM1 by modified thiazolidinediones. Eur J Med Chem. 2021; 209: 112902. DOI: 10.1016/j.ejmech.2020.112902.

59. Liu $Y$, Peng $X$, Li H, Jiao W, Peng $X$, Shao J, et al. STAT3 inhibitor napabucasin inhibits tumor growth and cooperates with proteasome inhibition in human ovarian cancer cells. Recent Pat Anticancer Drug Discov. 2021. DOI: 10.2174/157489281666621 0224155403

60. Wang X, Wu K, Fang L, Yang X, Zheng N, Du Z, et al. Discovery of $\mathrm{N}$-substituted sulfamoylbenzamide derivatives as novel inhibitors of STAT3 signaling pathway based on Niclosamide. Eur J Med Chem. 2021; 218:113362. DOI: 10.1016/j.ejmech.2021.113362.

61. Zhang J, Li C, Zhang L, Heng Y, Xu T, Zhang Y, et al. Andrographolide induces noxa-dependent apoptosis by transactivating atf4 in human lung adenocarcinoma cells. Front Pharmacol. 2021; 12: 680589. DOl:10.3389/fphar.2021.680589.

62. Ibrahim TS, Hawwas MM, Taher ES, Alhakamy NA, Alfaleh MA, Elagawany $\mathrm{M}$, et al. Design and synthesis of novel pyrazolo[3,4-d] pyrimidin-4-one bearing quinoline scaffold as potent dual PDE5 inhibitors and apoptotic inducers for cancer therapy. Bioorg Chem. 2020; 105: 104352. DOI: 10.1016/j.bioorg.2020.104352.

63. Abosharaf HA, Diab T, Atlam FM, Mohamed TM. Osthole extracted from a citrus fruit that affects apoptosis on A549 cell line by histone deacetylasese inhibition (HDACs). Biotechnol Rep (Amst). 2020; 28: e00531. DOI: 10.1016/j.btre.2020.e00531.

64. Xie Z, Wang F, Lin L, Duan S, Liu X, Li X, et al. An SGLT2 inhibitor modulates $\mathrm{SHH}$ expression by activating AMPK to inhibit the migration and induce the apoptosis of cervical carcinoma cells. Cancer Lett. 2020; 495: 200-10. DOI: 10.1016/j. canlet.2020.09.005.

65. Watanabe S, Nishijima N, Hirai K, Shibata K, Hase A, Yamanaka T, et al. Anticancer activity of amb4269951, a choline transporter-like protein 1 inhibitor, in human glioma cells. Pharmaceuticals (Basel). 2020; 13 (5): 104. DOI: 10.3390/ph13050104.

66. Hyun SY, Le HT, Min HY, Pei H, Lim Y, Song I, et al. Evodiamine inhibits both stem cell and non-stem-cell populations in human cancer cells by targeting heat shock protein 70 . Theranostics. 2021; 11 (6): 2932-52. DOI: 10.7150/thno.49876.

67. Tentori L, Dorio AS, Mazzon E, Muzi A, Sau A, Cuzzocrea S, et al. The glutathione transferase inhibitor 6-(7-nitro-2,1,3-benzoxadiazol4-ylthio)hexanol (NBDHEX) increases temozolomide efficacy against malignant melanoma. Eur J Cancer. 2011; 47(8): 1219-30. DOI: 10.1016/j.ejca.2010.12.008.

68. Altamura G, Degli Uberti B, Galiero G, De Luca G, Power K, Licenziato $L$, et al. The small molecule BIBR1532 exerts potential anti-cancer activities in preclinical models of feline oral squamous cell carcinoma through inhibition of telomerase activity and downregulation of TERT. Front Vet Sci. 2021; 7: 620776. DOI: 10.3389/ fvets.2020.620776.

69. Wang J, lannarelli R, Pucciarelli S, Laudadio E, Galeazzi R, Giangrossi $\mathrm{M}$, et al. Acetylshikonin isolated from Lithospermum erythrorhizon roots inhibits dihydrofolate reductase and hampers autochthonous mammary carcinogenesis in $\triangle 16 \mathrm{HER} 2$ transgenic mice. Pharmacol Res. 2020; 161: 105123. DOl: 10.1016/j. phrs.2020.105123.

70. Ding $W$, Zhang $H$, Mei G. Synergistic antitumor activity of DHA and JQ1 in colorectal carcinoma. Eur J Pharmacol. 2020; 885: 173500. DOI: 10.1016/j.ejphar.2020.173500.

71. Yuan LW, Jiang XM, Xu YL, Huang MY, Chen YC, Yu WB, et al. 
Licochalcone A inhibits interferon-gamma-induced programmed death-ligand 1 in lung cancer cells. Phytomedicine. 2021; 80: 153394. DOI:10.1016/j.phymed.2020.153394.

72. Boichuk S, Galembikova A, Bikinieva F, Dunaev P, Aukhadieva A, Syuzov K, et al. 2-APCAs, the novel microtubule targeting agents active against distinct cancer cell lines. Molecules. 2021; 26 (3): 616. DOI: 10.3390/molecules26030616.

73. Lin S, Liang Y, Cheng J, Pan F, Wang Y. Novel diaryl-2H-azirines: Antitumor hybrids for dual-targeting tubulin and DNA. Eur J Med Chem. 2021; 214: 113256. DOI: 10.1016/j.ejmech.2021.113256.

74. Sardaru MC, Craciun AM, Al Matarneh CM, Sandu IA, Amarandi RM, Popovici L, et al. Cytotoxic substituted indolizines as new colchicine site tubulin polymerisation inhibitors. J Enzyme Inhib Med Chem. 2020; 35 (1): 1581-95. DOI: 10.1080/14756366.2020.1801671.

75. Li X, Liu Y, Zhao Y, Tian W, Zhai L, Pang $\mathrm{H}$, et al. Rhein derivative $4 \mathrm{f}$ inhibits the malignant phenotype of breast cancer by downregulating Rac1 protein. Front Pharmacol. 2020; 11: 754. DOI: $10.3389 /$ fphar.2020.00754.

76. Yao Y, Yao QY, Xue JS, Tian XY, An QM, Cui LX, et al, Dexamethasone inhibits pancreatic tumor growth in preclinical models: Involvement of activating glucocorticoid receptor. Toxicol Appl Pharmacol. 2020; 401: 115118. DOI: 10.1016/j. taap.2020.115118.

77. Wang SS, Zhang QL, Chu P, Kong LQ, Li GZ, Li YQ, et al. Synthesis and antitumor activity of $\alpha, \beta$-unsaturated carbonyl moiety-containing oleanolic acid derivatives targeting PI3K/AKT/ mTOR signaling pathway. Bioorg Chem. 2020; 101: 104036. DOI: 10.1016/j.bioorg.2020.104036.

78. Liu H, Li X, Duan Y, Xie JB, Piao XL. Mechanism of gypenosides of Gynostemma pentaphyllum inducing apoptosis of renal cell carcinoma by PI3K/AKT/mTOR pathway. J Ethnopharmacol. 2021; 271: 113907. DOI: 10.1016/j.jep.2021.113907.

79. Li X, Zhao J, Yan T, Mu J, Lin Y, Chen J, et al. Cyanidin-3-Oglucoside and cisplatin inhibit proliferation and downregulate the PI3K/AKT/mTOR pathway in cervical cancer cells. J Food Sci. 2021. Available from: https://onlinelibrary.wiley. com/doi/10.1111/1750-3841.15740. DOI: 10.1111/17503841.15740

80. Ma W, Zhang Q, Li X, Ma Y, Liu Y, Hu S, et al. IPM712, a vanillin derivative as potential antitumor agents, displays better antitumor activity in colorectal cancers cell lines. Eur J Pharm Sci. 2020; 152: 105464. DOI: 10.1016/j.ejps.2020.105464.

81. Han Y, Tian Y, Wang R, Fu S, Jiang J, Dong J, et al. Design, synthesis and biological evaluation of thieno[3,2-d]pyrimidine derivatives containing aroyl hydrazone or aryl hydrazide moieties for PI3K and mTOR dual inhibition. Bioorg Chem. 2020; 104: 104197. DOI: 10.1016/j.bioorg.2020.104197.

82. Wang T, Wang J, Ren W, Liu ZL, Cheng YF, Zhang XM. Combination treatment with artemisinin and oxaliplatin inhibits tumorigenesis in esophageal cancer EC109 cell through Wnt/ $\beta$ catenin signaling pathway. Thorac Cancer. 2020; 11 (8): 2316-24. DOI: 10.1111/1759-7714.13570.

83. Gabata R, Harada K, Mizutani $Y$, Ouchi H, Yoshimura K, Sato $Y$, et al. Anti-tumor activity of the small molecule inhibitor PRI-724 against $\beta$-catenin-activated hepatocellular carcinoma. Anticancer Res. 2020; 40 (9): 5211-19. DOI: 10.21873/anticanres.14524.

84. Shang FF, Wang JY, Xu Q, Deng H, Guo HY, Jin X, et al. Design, synthesis of novel celastrol derivatives and study on their antitumor growth through $\mathrm{HIF-1} \alpha$ pathway. Eur J Med Chem. 2021; 220: 113474. Available from: https://www.sciencedirect. com/science/article/abs/pii/S0223523421003238?via\%3Dihub. DOI: 10.1016/j.ejmech.2021.113474.

\section{Литература}

1. Kiriiri GK, Njogu PM, Mwangi AN. Exploring different approaches to improve the success of drug discovery and development projects: a review. Futur J Pharm Sci. 2020; 6: 27. DOI: 10.1186/ s43094-020-00047-9.

2. Gibbs JB. Mechanism-based target identification and drug discovery in cancer research. Science. 2000; 287 (5460): 1969-
85. Ge $\mathrm{Y}$, Yoon $\mathrm{SH}$, Jang $\mathrm{H}$, Jeong JH, Lee $\mathrm{YM}$. Decursin promotes $\mathrm{HIF}-1 \alpha$ proteasomal degradation and immune responses in hypoxic tumour microenvironment. Phytomedicine. 2020; 78: 153318. DOI:10.1016/. phymed.2020.153318.

86. Kang DY, Sp N, Lee JM, Jang KJ. Antitumor effects of ursolic acid through mediating the inhibition of STAT3/PD-L1 signaling in non-small cell lung cancer cells. Biomedicines. 2021; 9 (3): 297. DOI:10.3390/biomedicines9030297.

87. Cui J, Li H, Wang Y, Tian T, Liu C, Wang Y, et al. Skullcapflavone I has a potent anti-pancreatic cancer activity by targeting miR-23a. Biofactors. 2020; 46 (5): 821-30. DOI: 10.1002/biof.1621.

88. Houssein M, Abi Saab W, Khalil M, Khalife H, Fatfat M. Cell death by gallotannin is associated with inhibition of the JAK/STAT pathway in human colon cancer cells. Curr Ther Res Clin Exp. 2020; 92: 100589. DOI: 10.1016/j.curtheres.2020.100589.

89. Luo W, Sun R, Chen X, Li J, Jiang J, He Y, et al. ERK activationmediated autophagy induction resists licochalcone a-induced anticancer activities in lung cancer cells in vitro. Onco Targets Ther. 2021; 13: 13437-50. DOI: 10.2147/OTT.S278268.

90. Zhang WH, Chen S, Liu XL, Bing-Lin, Liu XW, Zhou Y. Study on antitumor activities of the chrysin-chromene-spirooxindole on Lewis lung carcinoma C57BL/6 mice in vivo. Bioorg Med Chem Lett. 2020; 30 (17): 127410. DOI: 10.1016/j.bmcl.2020.127410.

91. Kwak AW, Yoon G, Lee MH, Cho SS, Shim JH, Chae J. Picropodophyllotoxin, an epimer of podophyllotoxin, causes apoptosis of human esophageal squamous cell carcinoma cells through ROS-mediated JNK/P38 MAPK pathways. Int J Mol Sci. 2020; 21 (13): 4640. DOI: 10.3390/ijms21134640.

92. Potočnjak I, Šimić L, Gobin I, Vukelić I, Domitrović R. Antitumor activity of luteolin in human colon cancer SW620 cells is mediated by the ERK/FOXO3a signaling pathway. Toxicol In Vitro. 2020; 66: 104852. DOI:10.1016/j.tiv.2020.104852.

93. Brooks JD, Teraoka SN, Bernstein L, Mellemkjær L, Malone KE, Lynch CF, et al. Common variants in genes coding for chemotherapy metabolizing enzymes, transporters, and targets: a case-control study of contralateral breast cancer risk in the WECARE Study. Cancer Causes Control. 2013; 24 (8): 1605-14. DOI: 10.1007/s10552-013-0237-6.

94. Bushweller $\mathrm{JH}$. Targeting transcription factors in cancer - from undruggable to reality. Nat Rev Cancer. 2019; 19 (11): 611-24. DOI: 10.1038/s41568-019-0196-7.

95. Lu H, Zhou Q, He J, Jiang Z, Peng C, Tong R, et al. Recent advances in the development of protein-protein interactions modulators: mechanisms and clinical trials. Signal Transduct Target Ther. 2020; 5 (1): 213. DOI: 10.1038/s41392-020-00315-3.

96. Ivanov AA, Khuri FR, Fu H. Targeting protein-protein interactions as an anticancer strategy. Trends Pharmacol Sci. 2013; 34 (7): 393-400. DOI: 10.1016/j.tips.2013.04.007.

97. Engin HB, Kreisberg JF, Carter H. Structure-based analysis reveals cancer missense mutations target protein interaction interfaces. PLoS One. 2016; 11 (4): e0152929. DOI: 10.1371/ journal.pone.0152929.

98. Porta-Pardo E, Garcia-Alonso L, Hrabe T, Dopazo J, Godzik A. A pan-cancer catalogue of cancer driver protein interaction interfaces. PLoS Comput Biol. 2015; 11 (10): e1004518. DOI: 10.1371/journal.pcbi.1004518.

99. Duffy MJ, Crown J. Drugging "undruggable" genes for cancer treatment: Are we making progress? Int J Cancer. 2021; 148 (1): 8-17. DOI: 10.1002/ijc.33197.

100. Santos R, Ursu O, Gaulton A, Bento AP, Donadi RS, Bologa CG, et al. A comprehensive map of molecular drug targets. Nat Rev Drug Discov. 2017; 16 (1): 19-34. DOI: 10.1038/nrd.2016.230.

73. DOl: 10.1126/science.287.5460.1969.

3. Druker BJ. Perspectives on the development of a molecularly targeted agent. Cancer Cell. 2002 Feb; 1 (1): 31-6. DOI: 10.1016/ s1535-6108(02)00025-9.

4. Nam NH, Parang K. Current targets for anticancer drug discovery. Curr Drug Targets. 2003; 4 (2): 159-79. DOI: 
10.2174/1389450033346966

5. Haider T, Pandey V, Banjare N, Gupta PN, Soni V. Drug resistance in cancer: mechanisms and tackling strategies. Pharmacol Rep. 2020; 72 (5): 1125-51. DOl:10.1007/s43440-020-00138-7.

6. Devlin EJ, Denson LA, Whitford HS. Cancer treatment side effects: A meta-analysis of the relationship between response expectancies and experience. J Pain Symptom Manage. 2017; 54 (2): 245-58.e2. DOI:10.1016/j.jpainsymman.2017.03.017.

7. Kumar B, Singh S, Skvortsova I, Kumar V. Promising targets in anti-cancer drug development: recent updates. Curr Med Chem. 2017; 24 (42): 4729-52. DOI: 10.2174/09298673246661703311 23648.

8. Magalhaes LG, Ferreira LLG, Andricopulo AD. Recent advances and perspectives in cancer drug design. An Acad Bras Cienc. 2018; 90 (1 Suppl 2): 1233-50. DOI: 10.1590/00013765201820170823.

9. Cui W, Aouidate A, Wang S, Yu Q, Li Y, Yuan S. Discovering anti-cancer drugs via computational methods. Front Pharmacol. 2020; 11: 733. DOI: 10.3389/fphar.2020.00733.

10. Özen Çınar İ. Bibliometric analysis of breast cancer research in the period 2009-2018. Int J Nurs Pract. 2020; 26 (3): e12845. DOl:10.1111/ijn.12845.

11. Didion CA, Henne WA. A bibliometric analysis of folate receptor research. BMC Cancer. 2020; 20 (1): 1109. DOI:10.1186/s12885020-07607-5.

12. Jin B, Wu XA, Du SD. Top 100 most frequently cited papers in liver cancer: a bibliometric analysis. ANZ J Surg. 2020; 90 (1-2): 21-6. DOI:10.1111/ans.15414.

13. Liu W, Wu L, Zhang Y, Shi L, Yang X. Bibliometric analysis of research trends and characteristics of oral potentially malignant disorders. Clin Oral Investig. 2020; 24 (1): 447-54. DOI: 10.1007/ s00784-019-02959-0.

14. Van Eck NJ, Waltman L. Text mining and visualization using VOSviewer. ISSI Newsletter. 2011; 7 (3): 50-4.

15. Tauno M, Jaak V. Clustvis: a web tool for visualizing clustering of multivariate data using Principal Component Analysis and heatmap. Nucleic Acids Research. 2015; 43 (W1): W566-W570, 2015. DOI: 10.1093/nar/gkv468.

16. Arnst KE, Banerjee S, Chen H, Deng S, Hwang DJ, Li W, et al. Current advances of tubulin inhibitors as dual acting small molecules for cancer therapy. Med Res Rev. 2019; 39 (4): 1398426. DOI:10.1002/med.21568.

17. Chopra B, Dhingra AK, Dhar KL, Nepali K. Emerging role of terpenoids for the treatment of cancer: a review. Mini Rev Med Chem. 2021. Available from: https://www.eurekaselect. com/190215/article. DOI: 10.2174/1389557521666210112143024.

18. Kirsch P, Hartman AM, Hirsch AKH, Empting M. Concepts and core principles of fragment-based drug design. Molecules. 2019; 24 (23): 4309. DOI: 10.3390/molecules24234309.

19. Giacomini E, Rupiani S, Guidotti L, Recanatini M, Roberti M. The use of stilbene scaffold in medicinal chemistry and multi-target drug design. Curr Med Chem. 2016; 23 (23): 2439-89. DOI: 10.2 174/0929867323666160517121629.

20. Hughes JP, Rees S, Kalindjian SB, Philpott KL. Principles of early drug discovery. Br J Pharmacol. 2011; 162 (6): 1239-49. DOl: 10.1111/j.1476-5381.2010.01127.x.

21. Lipinski CA, Lombardo F, Dominy BW, Feeney PJ. Experimental and computational approaches to estimate solubility and permeability in drug discovery and development settings. Adv Drug Deliv Rev. 1997; 23 (1-3): 3-25. DOI: 10.1016/S0169-409X(96)00423-1.

22. Garcia da Silva AC, Rodrigues BDS, Andrade WM, Marques Dos Santos TR, de Carvalho FS, Sanz G, et al. Antiangiogenic and antitumoral activity of LQFM126 prototype against B16F10 melanoma cells. Chem Biol Interact. 2020; 325: 109127. DOI: 10.1016/j.cbi.2020.109127.

23. Yamada K, Hori Y, Inoue S, Yamamoto Y, Iso K, Kamiyama H, et al. E7386, a selective inhibitor of the interaction between $\beta$-catenin and CBP, exerts antitumor activity in tumor models with activated canonical Wnt signaling. Cancer Res. 2021; 81 (4): 1052-62. DOl: 10.1158/0008-5472.CAN-20-0782.

24. Zhang YF, Zhang ZH, Li MY, Wang JY, Xing Y, Ri M, et al. Britannin stabilizes $T$ cell activity and inhibits proliferation and angiogenesis by targeting PD-L1 via abrogation of the crosstalk between Myc and HIF-1 $\alpha$ in cancer. Phytomedicine. 2021; 81: 153425. DOl: 10.1016/j.phymed.2020.153425

25. Yoon SH, Kim BK, Kang MJ, Im JY, Won M. Miconazole inhibits signal transducer and activator of transcription 3 signaling by preventing its interaction with DNA damage-induced apoptosis suppressor. Cancer Sci. 2020 Jul; 111 (7): 2499-507. DOl: 10.1111/cas.14432. Epub 2020 May 31. PMID: 32476221; PMCID: PMC7385363.

26. Osmaniye D, Korkut Çelikateş B, Sağlık BN, Levent S, Acar Çevik U, Kaya Çavuşoğlu B, et al. Synthesis of some new benzoxazole derivatives and investigation of their anticancer activities. Eur J Med Chem. 2021; 210: 112979. DOI: 10.1016/j. ejmech.2020.112979.

27. Zhang N, Wang J, Sheng A, Huang S, Tang $Y$, Ma S, et al. Emodin inhibits the proliferation of MCF-7 human breast cancer cells through activation of aryl hydrocarbon receptor (AhR). Front Pharmacol. 2021; 11: 622046. DOI: 10.3389/fphar.2020.622046.

28. Qin J, Liu J, Wu C, Xu J, Tang B, Guo K, et al. Synthesis and biological evaluation of (3/4-(pyrimidin-2-ylamino) benzoyl)-based hydrazine-1 carboxamide/carbothioamide derivatives as novel $\mathrm{RXR} \alpha$ antagonists. J Enzyme Inhib Med Chem. 2020; 35 (1): 880-96. DOl: 10.1080/14756366.2020.1740692.

29. Zi CT, Yang L, Hu Y, Zhang P, Tang H, Zhang BL, et al. Synthesis, antitumor activity, and molecular docking of (-)-epigallocatechin3-gallate-4ß-triazolopodophyllotoxin conjugates. J Asian Nat Prod Res. 2020: 1-9. DOI: 10.1080/10286020.2020.1786066.

30. Huang WY, Zhang XR, Lyu L, Wang SQ, Zhang XT. Pyridazino[1,6-b]quinazolinones as new anticancer scaffold: synthesis, DNA intercalation, topoisomerase I inhibition and antitumor evaluation in vitro and in vivo. Bioorg Chem. 2020; 99: 103814. DOI: 10.1016/j.bioorg.2020.103814.

31. Karatas E, Foto E, Ertan-Bolelli T, Yalcin-Ozkat G, Yilmaz S, Ataei S, et al. Discovery of 5-(or 6)-benzoxazoles and oxazolo[4,5-b]pyridines as novel candidate antitumor agents targeting hTopo $\| \alpha$. Bioorg Chem. 2021; 112: 104913. DOI: 10.1016/j.bioorg.2021.104913.

32. Fukuda T, Nanjo Y, Fujimoto M, Yoshida K, Natsui Y, Ishibashi F, et al. Lamellarin-inspired potent topoisomerase I inhibitors with the unprecedented benzo[g][1]benzopyrano[4,3-b]indol-6(13H)one scaffold. Bioorg Med Chem. 2019; 27 (2): 265-77. DOl: 10.1016/j.bmc.2018.11.037.

33. Acar Çevik U, Sağlık BN, Osmaniye D, Levent S, Kaya Çavuşoğlu B, Karaduman $A B$, et al. Synthesis, anticancer evaluation and molecular docking studies of new benzimidazole-1,3,4oxadiazole derivatives as human topoisomerase types I poison. J Enzyme Inhib Med Chem. 2020; 35 (1): 1657-73. DOl: 10.1080/14756366.2020.1806831.

34. Song Y, Feng S, Feng J, Dong J, Yang K, Liu Z, et al. Synthesis and biological evaluation of novel pyrazoline derivatives containing indole skeleton as anti-cancer agents targeting topoisomerase II. Eur J Med Chem. 2020; 200: 112459. DOI: 10.1016/j. ejmech.2020.112459.

35. Al-Wahaibi LH, Gouda AM, Abou-Ghadir OF, Salem OIA, Ali AT, Farghaly HS, et al. Design and synthesis of novel 2,3-dihydropyrazino[1,2-a]indole-1,4-dione derivatives as antiproliferative EGFR and BRAFV600E dual inhibitors. Bioorg Chem. 2020; 104: 104260. DOI: 10.1016/j.bioorg.2020.104260.

36. Eissa $H$, Ibrahim MK, Metwaly AM, Belal A, Mehany ABM, Abdelhady AA, et al. Design, molecular docking, in vitro, and in vivo studies of new quinazolin-4(3H)-ones as VEGFR-2 inhibitors with potential activity against hepatocellular carcinoma. Bioorg Chem. 2021; 107: 104532. DOI: 10.1016/j.bioorg.2020.104532.

37. Dai MD, Wang YL, Fan J, Dai Y, Ji YC, Sun YM, et al. DW14383 is an irreversible pan-FGFR inhibitor that suppresses FGFRdependent tumor growth in vitro and in vivo. Acta Pharmacol Sin. 2020. Available from: https://www.nature.com/articles/s41401020-00567-3. DOI: 10.1038/s41401-020-00567-3.

38. Ahmed MF, Santali EY, El-Haggar R. Novel piperazine-chalcone hybrids and related pyrazoline analogues targeting VEGFR-2 kinase; design, synthesis, molecular docking studies, and anticancer evaluation. J Enzyme Inhib Med Chem. 2021; 36 (1): 307-18. DOI: 10.1080/14756366.2020.1861606.

39. Zhuo LS, Wu FX, Wang MS, Xu HC, Yang FP, Tian YG, et al. Structure-activity relationship study of novel quinazoline-based 
1,6-naphthyridinones as MET inhibitors with potent antitumor efficacy. Eur J Med Chem. 2020; 208: 112785. DOI: 10.1016/j. ejmech.2020.112785.

40. Nan X, Zhang J, Li HJ, Wu R, Fang SB, Zhang ZZ, et al. Design, synthesis and biological evaluation of novel $\mathrm{N}$-sulfonylamidinebased derivatives as C-Met inhibitors via Cu-catalyzed threecomponent reaction. Eur J Med Chem. 2020; 200: 112470. DOI: 10.1016/.ejmech.2020.112470.

41. Krishan S, Sahni S, Richardson DR. The anti-tumor agent, Dp44mT, promotes nuclear translocation of TFEB via inhibition of the AMPK-mTORC1 axis. Biochim Biophys Acta Mol Basis Dis. 2020; 1866 (12): 165970. DOI: 10.1016/j.bbadis.2020.165970.

42. Cullen JK, Boyle GM, Yap PY, Elmlinger S, Simmons JL, Broit N, et al. Activation of PKC supports the anticancer activity of tigilano tiglate and related epoxytiglianes. Sci Rep. 2021; 11 (1): 207. DOl: 10.1038/s41598-020-80397-9.

43. Wagner E, Wietrzyk J, Psurski M, Becan L, Turlej E. Synthesis and anticancer evaluation of novel derivatives of isoxazolo[4,5-e] $[1,2,4]$ triazepine derivatives and potential inhibitors of protein kinase C. ACS Omega. 2020; 6 (1): 119-34. DOl:10.1021/ acsomega.0c03801.

44. Gilles P, Kashyap RS, Freitas MJ, Ceusters S, Van Asch K, Janssens A, et al. Design, synthesis and biological evaluation of pyrazolo[3,4-d]pyrimidine-based protein kinase D inhibitors. Eur J Med Chem. 2020; 205: 112638. DOI: 10.1016/j. ejmech.2020.112638.

45. Sootome H, Miura A, Masuko N, Suzuki T, Uto $\mathrm{Y}$, Hirai $\mathrm{H}$, et al. Inhibitor TAS-119 enhances antitumor efficacy of taxanes in vitro and in vivo: preclinical studies as guidance for clinical development and trial design. Mol Cancer Ther. 2020; 19 (10): 1981-91. DOl: 10.1158/1535-7163.MCT-20-0036.

46. Kar S, Ramamoorthy G, Mitra K, Shivalingegowda N, Mahesha, Mavileti SK, et al. Synthesis of novel spirobibenzopyrans as potent anticancer leads inducing apoptosis in HeLa cells. Bioorg Med Chem Lett. 2020; 30 (12): 127199. DOI: 10.1016/j. bmcl.2020.127199.

47. Massaro M, Barone G, Barra V, Cancemi P, Di Leonardo A Grossi G, et al. Pyrazole[3,4-d]pyrimidine derivatives loaded into halloysite as potential CDK inhibitors. Int J Pharm. 2021; 599: 120281. DOI: 10.1016/j.jijpharm.2021.120281.

48. Ismail MI, Mohamady S, Samir N, Abouzid KAM. Design, synthesis, and biological evaluation of novel $7 \mathrm{H}$-[1,2,4]triazolo[3,4-b][1,3,4] thiadiazine inhibitors as antitumor agents. ACS Omega. 2020; 5 (32): 20170-86. DOI: 10.1021/acsomega.0c01829.

49. Zhang ZY, Dong SM, Liu YH, Zhang MM, Zhang JK, Zhu HJ, et al. Enhanced anticancer activity by the combination of vinpocetine and sorafenib via PI3K/AKT/GSK-3 $\beta$ signaling axis in hepatocellular carcinoma cells. Anticancer Drugs. 2021. Available from: https://journals.Iww.com/anti-cancerdrugs/ Abstract/2021/09000/Enhanced_anticancer_activity_by_the_ combination_of.7.aspx. DOI: 10.1097/CAD.0000000000001056.

50. Zeytün E, Altıntop MD, Sever B, Özdemir A, Ellakwa DE, Ocak Z, et al. A new series of antileukemic agents: design, synthesis, in vitro and in silico evaluation of thiazole-based abl1 kinase inhibitors. Anticancer Agents Med Chem. 2021; 21 (9): 1099-109. DOI: 10. 2174/1871520620666200824100408.

51. Wang Y, LV Z, Chen F, Wang X, Gou S. Discovery of 5-(3-chlorophenylamino) benzo[c][2,6] naphthyridine derivatives as highly selective ck2 inhibitors with potent cancer cell stemness inhibition. J Med Chem. 2021; 64 (8): 5082-98. DOI: 10.1021/ acs.jmedchem.1c00131.

52. Yang $H$, Wang $X$, Wang $C$, Yin F, Qu L, Shi $C$ et al. Optimization of WZ4003 as NUAK inhibitors against human colorectal cancer. Eur J Med Chem. 2021; 210: 113080. DOI: 10.1016/j. ejmech.2020.113080.

53. Wu Q, Chen DQ, Sun L, Huan XJ, Bao XB, Tian CQ et al. Nove bivalent BET inhibitor N2817 exhibits potent anticancer activity and inhibits TAF1. Biochem Pharmacol. 2021; 185: 114435. DOI: 10.1016/j.bcp.2021.114435

54. Gan L, Gan Z, Dan Y, Li Y, Zhang P, Chen S, et al. Tetrazanbigen derivatives as peroxisome proliferator-activated receptor gamma (ppary) partial agonists: design, synthesis, structure-activity relationship, and anticancer activities. J Med Chem. 2021; 64 (2):
1018-36. DOI: 10.1021/acs.jmedchem.0c01512.

55. Zhang D, Sun G, Peng L, Tian J, Zhang H. Calycosin inhibits viability, induces apoptosis, and suppresses invasion of cervical cancer cells by upregulating tumor suppressor miR-375. Arch Biochem Biophys. 2020; 691: 108478. DOI: 10.1016/j. abb.2020.108478.

56. Szczuka I, Wiśniewski J, Kustrzeba-Wójcicka I, Terlecki G. The effect of 3-bromopyruvate on the properties of cathepsin B in the aspect of metastatic potential of colon cancer cells. Adv Clin Exp Med. 2020; 29 (8): 949-57. DOI: 10.17219/acem/123622. PMID: 32820873.

57. Ge $\mathrm{Y}$, Yoon $\mathrm{SH}$, Jang $\mathrm{H}$, Jeong $\mathrm{JH}$, Lee $\mathrm{YM}$. Decursin promotes $\mathrm{HIF-1} \alpha$ proteasomal degradation and immune responses in hypoxic tumour microenvironment. Phytomedicine. 2020; 78: 153318. DOI: 10.1016/j.phymed.2020.153318.

58. Tabatabaei Dakhili SA, Pérez DJ, Gopal K, Haque M, Ussher JR, Kashfi K, et al. SP1-independent inhibition of FOXM1 by modified thiazolidinediones. Eur J Med Chem. 2021; 209: 112902. DOl: 10.1016/.ejmech.2020.112902.

59. Liu Y, Peng X, Li H, Jiao W, Peng X, Shao J, et al. STAT3 inhibitor napabucasin inhibits tumor growth and cooperates with proteasome inhibition in human ovarian cancer cells. Recent Pat Anticancer Drug Discov. 2021. DOI: 10.2174/157489281666621 0224155403.

60. Wang X, Wu K, Fang L, Yang X, Zheng N, Du Z, et al. Discovery of $\mathrm{N}$-substituted sulfamoylbenzamide derivatives as novel inhibitors of STAT3 signaling pathway based on Niclosamide. Eur J Med Chem. 2021; 218:113362. DOI: 10.1016/j.ejmech.2021.113362.

61. Zhang J, LiC, Zhang L, Heng Y, Xu T, Zhang Y, et al. Andrographolide induces noxa-dependent apoptosis by transactivating atf4 in human lung adenocarcinoma cells. Front Pharmacol. 2021; 12: 680589. DOI:10.3389/fphar.2021.680589.

62. Ibrahim TS, Hawwas MM, Taher ES, Alhakamy NA, Alfaleh MA, Elagawany $\mathrm{M}$, et al. Design and synthesis of novel pyrazolo[3,4-d] pyrimidin-4-one bearing quinoline scaffold as potent dual PDE5 inhibitors and apoptotic inducers for cancer therapy. Bioorg Chem. 2020; 105: 104352. DOI: 10.1016/j.bioorg.2020.104352.

63. Abosharaf HA, Diab T, Atlam FM, Mohamed TM. Osthole extracted from a citrus fruit that affects apoptosis on A549 cell line by histone deacetylasese inhibition (HDACs). Biotechnol Rep (Amst). 2020; 28: e00531. DOI: 10.1016/j.btre.2020.e00531.

64. Xie Z, Wang F, Lin L, Duan S, Liu X, Li X, et al. An SGLT2 inhibitor modulates $\mathrm{SHH}$ expression by activating AMPK to inhibit the migration and induce the apoptosis of cervical carcinoma cells. Cancer Lett. 2020; 495: 200-10. DOI: 10.1016/j. canlet.2020.09.005.

65. Watanabe S, Nishiijma N, Hirai K, Shibata K, Hase A, Yamanaka T, et al. Anticancer activity of amb4269951, a choline transporter-like protein 1 inhibitor, in human glioma cells. Pharmaceuticals (Basel). 2020; 13 (5): 104. DOI: 10.3390/ph13050104.

66. Hyun SY, Le HT, Min HY, Pei H, Lim Y, Song I, et al. Evodiamine inhibits both stem cell and non-stem-cell populations in human cancer cells by targeting heat shock protein 70 . Theranostics. 2021; 11 (6): 2932-52. DOI: 10.7150/thno.49876.

67. Tentori L, Dorio AS, Mazzon E, Muzi A, Sau A, Cuzzocrea S, et al. The glutathione transferase inhibitor 6-(7-nitro-2,1,3-benzoxadiazol4-ylthio)hexanol (NBDHEX) increases temozolomide efficacy against malignant melanoma. Eur J Cancer. 2011; 47(8): 1219-30. DOI: 10.1016/j.ejca.2010.12.008

68. Altamura G, Degli Uberti B, Galiero G, De Luca G, Power K, Licenziato $L$, et al. The small molecule BIBR1532 exerts potential anti-cancer activities in preclinical models of feline oral squamous cell carcinoma through inhibition of telomerase activity and downregulation of TERT. Front Vet Sci. 2021; 7: 620776. DOI: 10.3389/ fvets.2020.620776.

69. Wang J, lannarelli R, Pucciarelli S, Laudadio E, Galeazzi R, Giangrossi $\mathrm{M}$, et al. Acetylshikonin isolated from Lithospermum erythrorhizon roots inhibits dihydrofolate reductase and hampers autochthonous mammary carcinogenesis in $\triangle 16 \mathrm{HER} 2$ transgenic mice. Pharmacol Res. 2020; 161: 105123. DOI: 10.1016/j. phrs.2020.105123.

70. Ding $W$, Zhang H, Mei G. Synergistic antitumor activity of DHA and JQ1 in colorectal carcinoma. Eur J Pharmacol. 2020; 885: 
173500. DOI: 10.1016/j.ejphar.2020.173500.

71. Yuan LW, Jiang XM, Xu YL, Huang MY, Chen YC, Yu WB, et al. Licochalcone $A$ inhibits interferon-gamma-induced programmed death-ligand 1 in lung cancer cells. Phytomedicine. 2021; 80: 153394. DOI:10.1016/j.phymed.2020.153394.

72. Boichuk S, Galembikova A, Bikinieva F, Dunaev P, Aukhadieva A, Syuzov K, et al. 2-APCAs, the novel microtubule targeting agents active against distinct cancer cell lines. Molecules. 2021; 26 (3): 616. DOI: 10.3390/molecules26030616.

73. Lin S, Liang Y, Cheng J, Pan F, Wang Y. Novel diaryl-2H-azirines: Antitumor hybrids for dual-targeting tubulin and DNA. Eur J Med Chem. 2021; 214: 113256. DOI: 10.1016/j.ejmech.2021.113256.

74. Sardaru MC, Craciun AM, Al Matarneh CM, Sandu IA, Amarandi RM Popovici L, et al. Cytotoxic substituted indolizines as new colchicine site tubulin polymerisation inhibitors. J Enzyme Inhib Med Chem. 2020; 35 (1): 1581-95. DOI: 10.1080/14756366.2020.1801671.

75. Li X, Liu Y, Zhao Y, Tian W, Zhai L, Pang H, et al. Rhein derivative $4 \mathrm{f}$ inhibits the malignant phenotype of breast cancer by downregulating Rac1 protein. Front Pharmacol. 2020; 11 754. DOI: 10.3389/fphar.2020.00754.

76. Yao Y, Yao QY, Xue JS, Tian XY, An QM, Cui LX, et al. Dexamethasone inhibits pancreatic tumor growth in preclinical models: Involvement of activating glucocorticoid receptor. Toxicol Appl Pharmacol. 2020; 401: 115118. DOI: 10.1016/j. taap.2020.115118.

77. Wang SS, Zhang QL, Chu P, Kong LQ, Li GZ, Li YQ, et al. Synthesis and antitumor activity of $\alpha, \beta$-unsaturated carbony moiety-containing oleanolic acid derivatives targeting PI3K/AKT/ mTOR signaling pathway. Bioorg Chem. 2020; 101: 104036. DOl: 10.1016/j.bioorg.2020.104036.

78. Liu H, Li X, Duan Y, Xie JB, Piao XL. Mechanism of gypenosides of Gynostemma pentaphyllum inducing apoptosis of renal cell carcinoma by PI3K/AKT/mTOR pathway. J Ethnopharmacol. 2021; 271: 113907. DOI: 10.1016/j.jep.2021.113907.

79. Li X, Zhao J, Yan T, Mu J, Lin Y, Chen J, et al. Cyanidin-3-Oglucoside and cisplatin inhibit proliferation and downregulate the PI3K/AKT/mTOR pathway in cervical cancer cells. $J$ Food Sci. 2021. Available from: https://onlinelibrary.wiley. com/doi/10.1111/1750-3841.15740. DOI: 10.1111/17503841.15740

80. Ma W, Zhang Q, Li X, Ma Y, Liu Y, Hu S, et al. IPM712, a vanillin derivative as potential antitumor agents, displays better antitumor activity in colorectal cancers cell lines. Eur J Pharm Sci. 2020; 152: 105464. DOI: 10.1016/j.ejps.2020.105464.

81. Han $Y$, Tian Y, Wang R, Fu S, Jiang J, Dong J, et al. Design, synthesis and biological evaluation of thieno[3,2-d]pyrimidine derivatives containing aroyl hydrazone or aryl hydrazide moieties for PI3K and mTOR dual inhibition. Bioorg Chem. 2020; 104: 104197. DOI: 10.1016/.bioorg.2020.104197.

82. Wang T, Wang J, Ren W, Liu ZL, Cheng YF, Zhang XM. Combination treatment with artemisinin and oxaliplatin inhibits tumorigenesis in esophageal cancer EC109 cell through Wnt/Bcatenin signaling pathway. Thorac Cancer. 2020; 11 (8): 2316-24. DOI: 10.1111/1759-7714.13570.

83. Gabata R, Harada K, Mizutani Y, Ouchi H, Yoshimura K, Sato Y, et al. Anti-tumor activity of the small molecule inhibitor PRI-724 against $\beta$-catenin-activated hepatocellular carcinoma. Anticancer Res. 2020; 40 (9): 5211-19. DOI: 10.21873/anticanres.14524.

84. Shang FF, Wang JY, Xu Q, Deng H, Guo HY, Jin X, et al. Design, synthesis of novel celastrol derivatives and study on their antitumor growth through HIF-1 $\alpha$ pathway. Eur J Med Chem. 2021; 220: 113474. Available from: https://www.sciencedirect. com/science/article/abs/pii/S0223523421003238?via\%3Dihub.
DOI: 10.1016/j.ejmech.2021.113474.

85. Ge Y, Yoon SH, Jang H, Jeong JH, Lee YM. Decursin promotes $\mathrm{HIF}-1 \alpha$ proteasomal degradation and immune responses in hypoxic tumour microenvironment. Phytomedicine. 2020; 78: 153318. DOI:10.1016/j.phymed.2020.153318.

86. Kang DY, Sp N, Lee JM, Jang KJ. Antitumor effects of ursolic acid through mediating the inhibition of STAT3/PD-L1 signaling in non-small cell lung cancer cells. Biomedicines. 2021; 9 (3): 297. DOI:10.3390/biomedicines9030297.

87. Cui J, Li H, Wang Y, Tian T, Liu C, Wang Y, et al. Skullcapflavone I has a potent anti-pancreatic cancer activity by targeting miR-23a. Biofactors. 2020; 46 (5): 821-30. DOI: 10.1002/biof.1621.

88. Houssein M, Abi Saab W, Khalil M, Khalife H, Fatfat M. Cell death by gallotannin is associated with inhibition of the JAK/STAT pathway in human colon cancer cells. Curr Ther Res Clin Exp. 2020; 92: 100589. DOI: 10.1016/j.curtheres.2020.100589.

89. Luo W, Sun R, Chen X, Li J, Jiang J, He Y, et al. ERK activationmediated autophagy induction resists licochalcone a-induced anticancer activities in lung cancer cells in vitro. Onco Targets Ther. 2021; 13: 13437-50. DOI: 10.2147/OTT.S278268.

90. Zhang WH, Chen S, Liu XL, Bing-Lin, Liu XW, Zhou Y. Study on antitumor activities of the chrysin-chromene-spirooxindole on Lewis lung carcinoma C57BL/6 mice in vivo. Bioorg Med Chem Lett. 2020; 30 (17): 127410. DOI: 10.1016/j.bmcl.2020.127410.

91. Kwak AW, Yoon G, Lee MH, Cho SS, Shim JH, Chae Jl. Picropodophyllotoxin, an epimer of podophyllotoxin, causes apoptosis of human esophageal squamous cell carcinoma cells through ROS-mediated JNK/P38 MAPK pathways. Int J Mol Sci. 2020; 21 (13): 4640. DOI: 10.3390/ijms21134640.

92. Potočnjak I, Šimić L, Gobin I, Vukelić I, Domitrović R. Antitumor activity of luteolin in human colon cancer SW620 cells is mediated by the ERK/FOXO3a signaling pathway. Toxicol In Vitro. 2020; 66: 104852. DOI:10.1016/j.tiv.2020.104852.

93. Brooks JD, Teraoka SN, Bernstein L, Mellemkjær L, Malone KE, Lynch CF, et al. Common variants in genes coding for chemotherapy metabolizing enzymes, transporters, and targets: a case-control study of contralateral breast cancer risk in the WECARE Study. Cancer Causes Control. 2013; 24 (8): 1605-14. DOI: 10.1007/s10552-013-0237-6.

94. Bushweller $\mathrm{JH}$. Targeting transcription factors in cancer - from undruggable to reality. Nat Rev Cancer. 2019; 19 (11): 611-24. DOI: 10.1038/s41568-019-0196-7.

95. Lu H, Zhou Q, He J, Jiang Z, Peng C, Tong R, et al. Recent advances in the development of protein-protein interactions modulators: mechanisms and clinical trials. Signal Transduct Target Ther. 2020; 5 (1): 213. DOI: 10.1038/s41392-020-00315-3.

96. Ivanov AA, Khuri FR, Fu H. Targeting protein-protein interactions as an anticancer strategy. Trends Pharmacol Sci. 2013; 34 (7): 393-400. DOI: 10.1016/j.tips.2013.04.007.

97. Engin HB, Kreisberg JF, Carter H. Structure-based analysis reveals cancer missense mutations target protein interaction interfaces. PLoS One. 2016; 11 (4): e0152929. DOI: 10.1371/ journal.pone.0152929.

98. Porta-Pardo E, Garcia-Alonso L, Hrabe T, Dopazo J, Godzik A. A pan-cancer catalogue of cancer driver protein interaction interfaces. PLoS Comput Biol. 2015; 11 (10): e1004518. DOI: 10.1371/journal.pcbi.1004518

99. Duffy MJ, Crown J. Drugging "undruggable" genes for cancer treatment: Are we making progress? Int J Cancer. 2021; 148 (1): 8-17. DOI: 10.1002/ijc.33197.

100. Santos R, Ursu O, Gaulton A, Bento AP, Donadi RS, Bologa CG, et al. A comprehensive map of molecular drug targets. Nat Rev Drug Discov. 2017; 16 (1): 19-34. DOI: 10.1038/nrd.2016.230. 